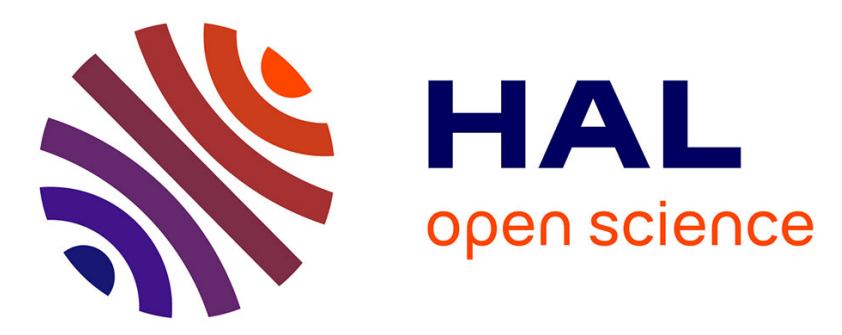

\title{
Multivalent DNA recognition by self-assembled clusters: deciphering structural effects by fragments screening and evaluation as siRNA vectors
}

Eline Bartolami, Yannick Bessin, Nadir Bettache, Magali Gary-Bobo, Marcel Garcia, Pascal Dumy, Sébastien Ulrich

\section{To cite this version:}

Eline Bartolami, Yannick Bessin, Nadir Bettache, Magali Gary-Bobo, Marcel Garcia, et al.. Multivalent DNA recognition by self-assembled clusters: deciphering structural effects by fragments screening and evaluation as siRNA vectors. Organic \& Biomolecular Chemistry, 2015, 13 (36), pp.9427 - 9438. 10.1039/c5ob01404b . hal-03116768

\section{HAL Id: hal-03116768 \\ https://hal.science/hal-03116768}

Submitted on 29 Sep 2021

HAL is a multi-disciplinary open access archive for the deposit and dissemination of scientific research documents, whether they are published or not. The documents may come from teaching and research institutions in France or abroad, or from public or private research centers.
L'archive ouverte pluridisciplinaire HAL, est destinée au dépôt et à la diffusion de documents scientifiques de niveau recherche, publiés ou non, émanant des établissements d'enseignement et de recherche français ou étrangers, des laboratoires publics ou privés. 


\section{Organic \& Biomolecular Chemistry}

\section{PAPER}

\section{Multivalent DNA recognition by self-assembled clusters: deciphering structural effects by fragments screening and evaluation as siRNA vectors}

Received 00th January 20xx, Accepted 00th January 20xx

DOI: $10.1039 / \times 0 \times x 00000 x$

www.rsc.org/

\author{
Eline Bartolami, Yannick Bessin, Nadir Bettache, ${ }^{*}$ Magali Gary-Bobo, Marcel Garcia, Pascal Dumy \\ and Sébastien Ulrich*
}

\section{Introduction}

Challenges in gene therapy. The prospect of treating the genetic root of diseases is a fascinating perspective of modern biotechnologies. Towards this goal, synthetic oligonucleotides represent therapeutic agents that can serve in antisense ${ }^{1}$ and silencing technologies. ${ }^{2}$ However, the effective and safe intracellular delivery of synthetic oligonucleotides remains a tremendous challenge. Oligonucleotides are negativelycharged biomolecules that are relatively unstable in biological medium - they undergo enzymatic degradation by nucleases and cannot pass cell membranes due to electrostatic repulsion. Thus, the success of oligonucleotide-based therapeutics depends greatly on the development of effective vectors. The serious immunogenic effects displayed by viral vectors ${ }^{3}$ call for an alternative bottom-up chemical approach. The design of synthetic systems that effectively complex and transport oligonucleotides is therefore a topic of great importance. ${ }^{4}$

Synthetic macromolecular vectors. Cationic polymers ${ }^{5}$ and dendrimers $^{6}$ have been extensively studied for the complexation and transport of oligonucleotides. In this case, the repetitions, within a single chain or compound, of multiple

Institut des Biomolécules Max Mousseron (IBMM), UMR 5247, CNRS, Université Montpellier, ENSCM, Ecole Nationale Supérieure de Chimie de Montpellier, 8 Rue de I'Ecole Normale, $34296 \quad$ Montpellier cedex 5, France

E-mail: nadir.bettache@univ-montp2.fr; Sebastien.Ulrich@enscm.fr.

† Electronic Supplementary Information (ESI) available: [details of any supplementary information available should be included here]. See DOI: $10.1039 / \times 0 \times x 00000 x$ binding units that promote complex formation with oligonucleotides exert a multivalent ${ }^{7}$ binding. However, the high molecular weight of these macromolecules is an issue and toxic side-effects have been observed due to their accumulation in biological tissues. ${ }^{8}$ A current approach for lifting these limitations focus on the generation of low-molecular-weight vectors that may be degradable and/or stimuli-responsive. ${ }^{9,} 10$

Multivalent DNA recognition by low-molecular-weight clusters. The multifunctionalization strategy (Scheme 1), whereby a scaffold is functionalized with multiple copies of a binding group through click-type reactions, has been recently exploited for generating low-molecular-weight cationic clusters that effectively complex oligonucleotides despite their limited valency with respect to polymers.

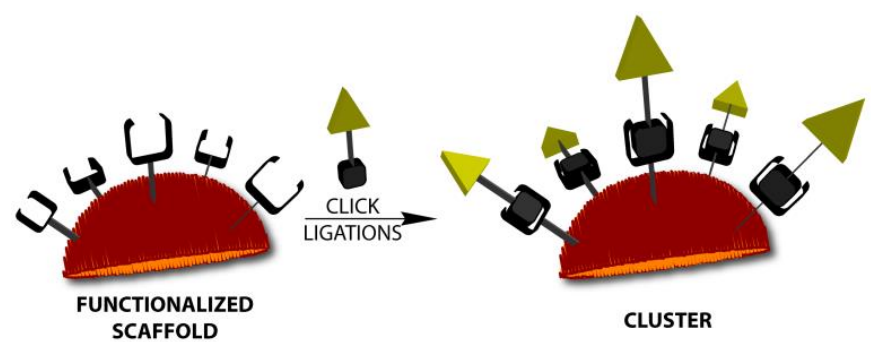

Scheme 1 Schematic representation of the principle of cluster formation by multiple click ligations of a binding group (yellow triangle) onto a functionalized scaffold.

Different examples of low-molecular-weight clusters based on a variety of scaffolds (calixarene, ${ }^{11}, 12$ fullerene, ${ }^{13}$ pillar[5]arene, ${ }^{14}$ cyclodextrines, ${ }^{15}$ and dendrimers ${ }^{16}$ ) and ligands (ammonium, guanidinium) have thus been reported. 
These systems represent promising alternatives to macromolecular vectors, provided their structures are finely tuned in order to optimize the multivalent binding to oligonucleotides. ${ }^{17}$ Effective screening methods are therefore needed for facilitating the identification of potent oligonucleotide-binding clusters.

We recently reported the generation of tetravalent biomolecular clusters based on cyclic peptide scaffolds for the multivalent recognition of DNA. ${ }^{18}$ In comparison with the most popular organic scaffolds, the use of biomolecules such as peptides as scaffolds is of interest in terms of biocompatibility. The selected bottom-up methodology rests upon the multifunctionalization of the cyclic peptide scaffold through acylhydrazone ligations. This type of ligation operates in mild aqueous conditions and can tolerate the presence of a complex biomolecular target such as DNA. Its chemoselectivity thus enables tethering in one-pot unprotected binding groups onto the scaffold. It is therefore a robust tool for programming the assembly of multiple fragments into a bioactive cluster. It has for instance been recently used by the Matile group for generating amphiphiles. ${ }^{19}$ The modularity of this fragmentassembly process of cluster formation through acylhydrazone ligations should enable the rapid screening of scaffolds and binding groups which, in turn, would help develop a better understanding of the molecular factors that determine the DNA-binding ability of these clusters. We report herein the results of a screening of different scaffolds and binding groups that are assembled together in a combinatorial fashion. The DNA-binding ability was directly analysed by a fluorescencedisplacement assay and cross-checked by gel electrophoresis. Finally, the best hits were evaluated on cell culture as potential siRNA vectors.

\section{Results and discussion}

\section{Design and synthesis of building blocks.}

The clusters are formed by tethering, through acylhydrazone ligations, hydrazide binding groups onto functionalized scaffolds featuring reactive aldehyde moieties (Scheme 1). The selected functionalized scaffolds bear a varying number (functionality $=1-4$ ) of reactive aldehyde groups (compounds A, Fig. 1). We selected different commercially-available compounds along with two synthetic - linear and cyclic peptides. Thus, these scaffolds feature different (bio)molecular structures and valency. The hydrazide partners are derivatives of amino acids and tripeptides bearing a hydrazide group at their C-terminus. They feature different types of side groups (neutral, hydrophobic, anionic, cationic), different stereochemistry, and different valency (compounds Hyd, Fig. $1)$.

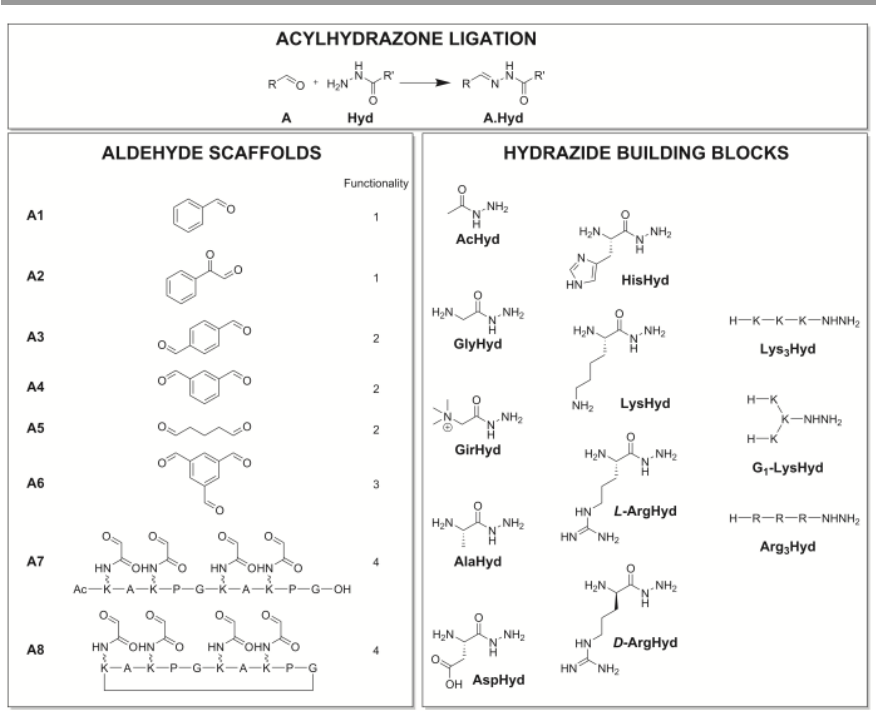

Fig. 1 Structure of aldehyde and hydrazide building blocks that are assembled through the acylhydrazone ligation.

The preparation of the linear peptide $\mathbf{A 7}$ was adapted from the synthesis of the cyclic peptide $\mathbf{A 8},{ }^{18}$ and involved solid-phase peptide synthesis, acetylation of the $\mathrm{N}$-terminal, cleavage and deprotection, and oxidative cleavage of serine side-chains to unmask the glyoxylic aldehydes.

The hydrazide partners were synthesized by a solid-phase approach using a Fmoc-protected hydrazine resin that can be readily prepared by reacting the 2-chlorotrityl chloride resin with Fmoc-hydrazide (Fig. 2). ${ }^{20}$ The amino acid hydrazides were prepared manually by peptide coupling, deprotection and cleavage. The tripeptide hydrazides were assembled using solid-phase peptide synthesis. After cleavage in mild acidic conditions, the protected peptides were purified by reversephase HPLC, before being fully deprotected to afford the tripeptide hydrazides.

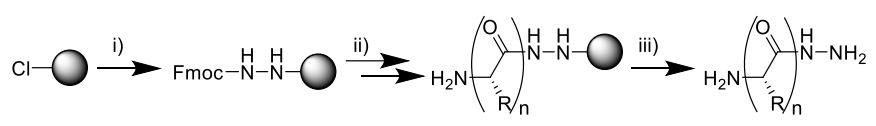

Fig. 2 Synthetic route for the preparation of amino acid and peptide hydrazides. i) Fmoc-hydrazide, DIEA; ii) a) deprotection: piperidine, b) peptide coupling: Fmocamino acid-OH, HATU, DIEA, c) deprotection: piperidine; iii) TFA/TIS/ $\mathrm{H}_{2} \mathrm{O}$.

\section{Self-assembly of clusters by acylhydrazone ligation.}

The ligation reactions were carried out, as previously described, in aqueous buffer (100 mM AcONa, pH 5.0), with 1 $\mathrm{mM}$ of scaffolds $\mathbf{A}$ and 8 equivalents of hydrazide per scaffold. These conditions favour the formation of the bioconjugates A.Hyd of highest valency. To verify this and to demonstrate that the ligation proceeds equally well with respect to the different types of building blocks, we tested the cluster formation of all hydrazides with scaffold $\mathbf{A} \mathbf{8}$ and of $\mathbf{A c H y d}$ with all scaffolds A. HPLC and mass spectrometry analyses confirm in all cases the formation of the corresponding clusters A.Hyd (see $\mathrm{SI}$ ). These conditions are therefore suitable for the modular self-assembly of clusters from different scaffolds and binding groups. We therefore envisaged carrying out a one-pot 
screening for rapidly identifying the structural determinants that favour multivalent DNA recognition.

\section{Screening.}

The ability of the different clusters to complex DNA was first assessed by a fluorescence displacement assay with ethidium bromide ( $\mathrm{EthBr}$ ) and calf thymus DNA (ctDNA). In this assay, a fluorescent emission decrease upon addition of a compound indicates its ability to complex DNA. This label-free assay is a simple method for establishing DNA binding affinity. ${ }^{21}$ It is also amenable to a high-throughput microplate format for enabling screening approaches, ${ }^{22}$ and it has already been used in this context for the determination of the DNA binding sequence selectivity of a ligand. ${ }^{23}$ In this study, we selected this assay for comparing the DNA-binding ability of clusters formed from the combinatorial association of different fragments (scaffolds and binding groups).

In each well of a 96-well plate, we deposited one aldehyde scaffold $\mathbf{A}$ and one hydrazide building block (8 eq). After overnight mixing, acetate buffer (100 mM, pH 5.0) of low salinity $(9.4 \mathrm{mM} \mathrm{NaCl})$ followed by ctDNA and $\mathrm{EthBr}$ were subsequently added. DNA complexation by clusters results in a fluorescence decrease that occurs within hours. The results show strong differences in the fluorescence emission, which indicates strong differences in DNA-binding properties (Fig. 3).

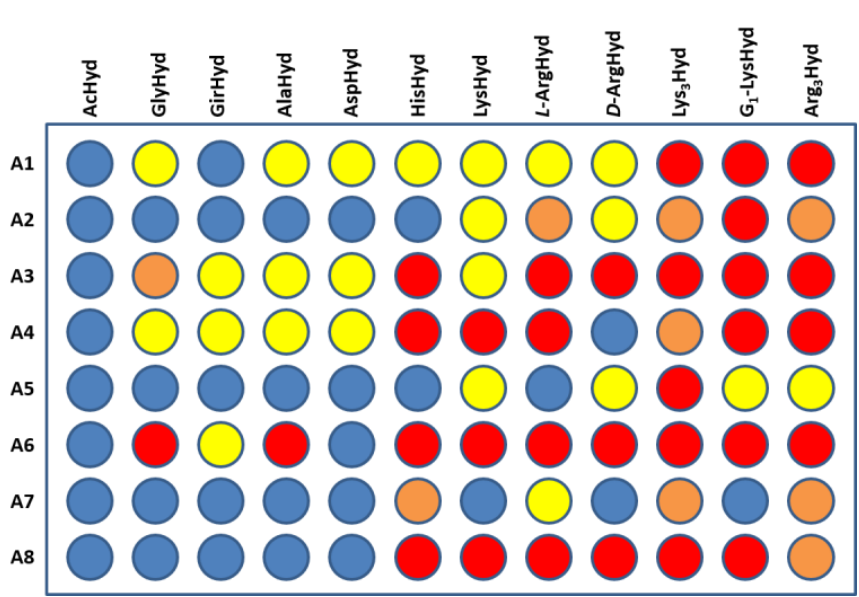

Fig. 3 Screening of a combinatorial array of aldehyde scaffolds $\mathbf{A}$ (left) and hydrazides binding groups (top) - assembled together by acylhydrazone ligations - by the ethidium bromide displacement assay with calf-thymus DNA target. Relative fluorescence

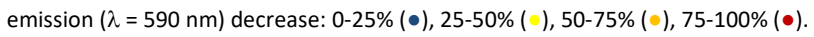
Measurements performed 6 hours after the addition of the DNA target.

When looking at the differences between the different hydrazide binding groups, one can note that no DNA complexation occurs with $\mathbf{A c H y d}$, regardless the nature of the scaffold it is assembled onto. In contrast, DNA complexation is detected with cationic binding groups. These results are in line with our previous observations that A8.Ac does not complex ctDNA while A8.L-Arg is an effective DNA-binding cluster, ${ }^{18}$ and thus validates this microplate format assay.

Effect of multivalency. These results suggest a multivalent effect since there are more hits with the tetravalent scaffold A8 than with the monovalent A1. The comparison of these results with the DNA-binding ability of individual components confirms that multivalency is a major factor that account for DNA-binding. Indeed, when tested alone by the EthBr assay, the individual aldehyde scaffolds $A$ were found unable to complex ctDNA under these conditions (Fig. 4). Similarly, the individual hydrazide binding groups show no DNA complexation under these conditions, except for the tripeptides Lys $_{3}$ Hyd, $\mathbf{G}_{1}$-LysHyd, and Arg $_{3} \mathrm{Hyd}$ (Fig. 4).

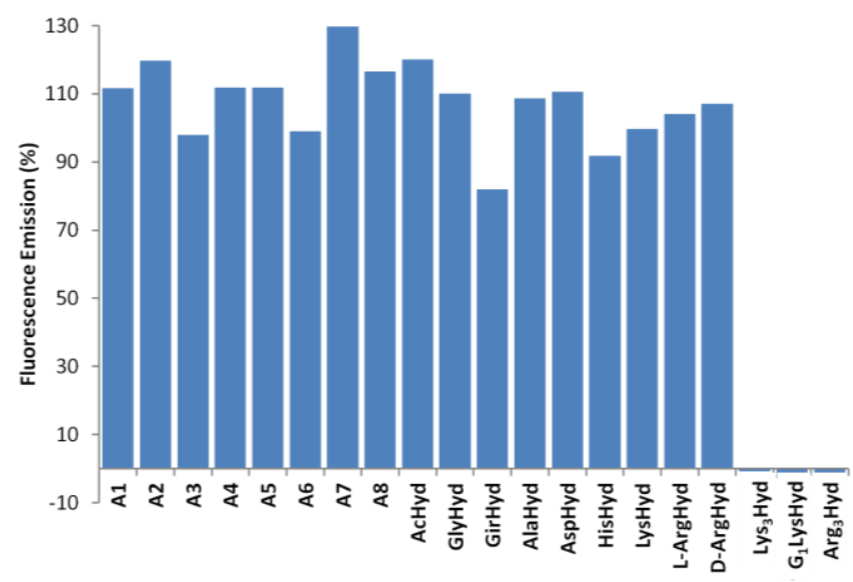

Fig. 4 DNA complexation by individual aldehyde scaffolds and hydrazide binding groups determined by EthBr assay.

Gel retardation assays confirm the role of multivalency and reveal the stoichiometry that is necessary for DNA binding expressed by the N/P ratio of positive charges brought by the clusters per negative charges in DNA. For instance, no complexation was detected with L-ArgHyd in the range of N/P $=20-500$ while the tetravalent cluster A8.L-Arg complexes plasmid DNA effectively at $\mathrm{N} / \mathrm{P} \geq 20 .{ }^{18}$ Similarly, we found that the tripeptide $\mathrm{Arg}_{3} \mathrm{Hyd}$ and the corresponding tetravalent cluster A8. Arg $_{3}$ complexes DNA at N/P $\geq 600$ and N/P $\geq 1$, respectively (Fig. 5).
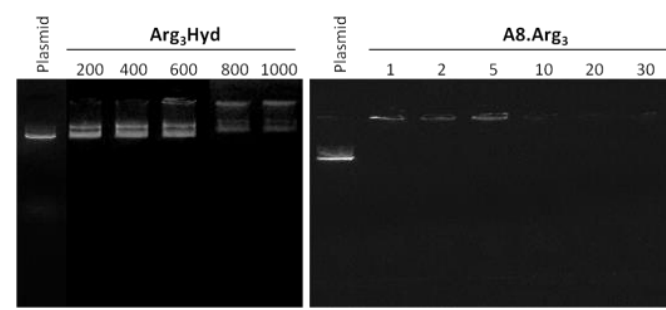

Fig. $5 \mathrm{Gel}$ electrophoresis analysis showing the complexation of plasmid DNA by the tripeptide $\mathbf{A r g}_{3} \mathbf{H y d}$ (left) and the corresponding tetravalent cluster $\mathbf{A 8 .} \mathbf{A r g}_{\mathbf{3}}$ (right) at different N/P.

Effect of scaffolds. With the L-ArgHyd binding group, we previously found that, when it is assembled onto the tetravalent scaffold $\mathbf{A 8}$, the corresponding cluster $\mathbf{A 8 . L - A r g}$ is an effective DNA-binding agent. ${ }^{18}$ The results of the EthBr screening assay indicate that both the valency and the structure of the scaffolds have a strong impact on the DNAbinding ability of these clusters. Thus, divalent scaffolds A3, A4 and tri- and tetra-valent scaffolds A6, A8 yield DNA-binding clusters. The gel retardation assay confirms the importance of 
scaffold structure but tends to indicate a weaker binding of the divalent clusters compared to the tri- and tetra-valent ones (Fig. 6).

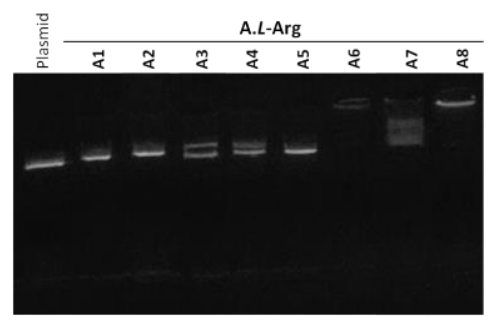

Fig. 6 Gel electrophoresis analysis showing the complexation of plasmid DNA by clusters made of different scaffolds A with hydrazide L-ArgHyd. Experiments carried out at $\mathrm{N} / \mathrm{P}=80$.

Similarly, with $\operatorname{Arg}_{3} \mathrm{Hyd}$, the gel retardation assay carried out at $\mathrm{N} / \mathrm{P}=1$ confirms the importance of the scaffold and reveals the superiority of the same scaffolds: A3, A4, A6, and A8 (Fig. 7).

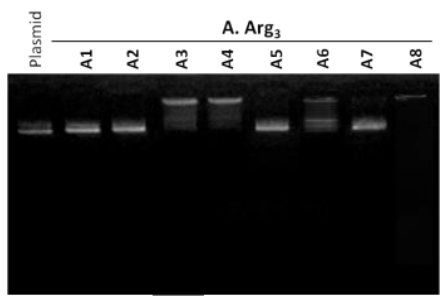

Fig. $7 \mathrm{Gel}$ electrophoresis analysis showing the complexation of plasmid DNA by clusters made of different scaffolds $\mathbf{A}$ with hydrazide $\mathbf{A r g}_{3} \mathbf{H y d}$. Experiments carried out at $\mathrm{N} / \mathrm{P}=1$.

Along these studies, we noticed a strong difference of DNAbinding ability between the clusters derived from the linear and cyclic scaffolds, respectively $\mathbf{A 7}$ and $\mathbf{A 8}$. According to EthBr displacement assay, the cyclic cluster is more effective than the linear one for DNA complexation. The gel retardation assay confirms the superiority of the cyclic cluster over the linear one. Indeed, while the cyclic cluster bind effectively plasmid DNA at $N / P \geq 20$, the linear cluster is only effective at $N / P \geq 50$ (Fig. 8).
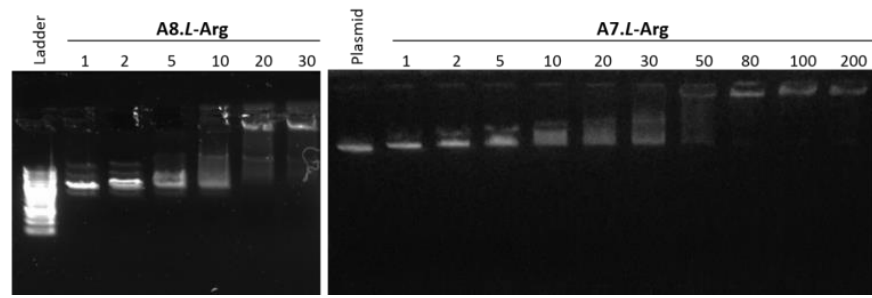

Fig. $8 \mathrm{Gel}$ electrophoresis analyses showing the complexation of plasmid DNA by clusters A8.L-Arg (left) and A7.L-Arg (right) at different N/P.

While it remains unclear why the cyclic scaffold leads to a more effective DNA complexation compared to the linear one, this observation has been previously made with other cationic clusters. ${ }^{12}$ In the present case, it is possible that the high preorganization offered by the constraint cyclic peptide scaffolds A8 is at the origin of this effect by increasing the local concentration of positive charges, thereby minimizing the entropic penalty upon binding.

Effect of binding groups. The screening result shows that, while neutral (AcHyd) or anionic hydrazide (AspHyd) give no sign of DNA complexation when assembled on a scaffold, not all cationic hydrazide give rise to DNA complexation when assembled on a scaffold. For instance, the clusters featuring the Girard's reagent (GirHyd) form poor DNA-binding agents with most scaffolds even though it is positively charged. This indicates that, while electrostatic interactions may be important for DNA complexation, other interactions such as hydrogen bonds must be considered as well. Gel retardation assay confirms the general trend obtained by the EthBr screening and indicates that, with the scaffold $\mathbf{A 8}$, amino acids and tripeptides that contain lysine or arginine are the best binding groups (Fig. 9). A similar preference was observed with the scaffold A6 (see SI).

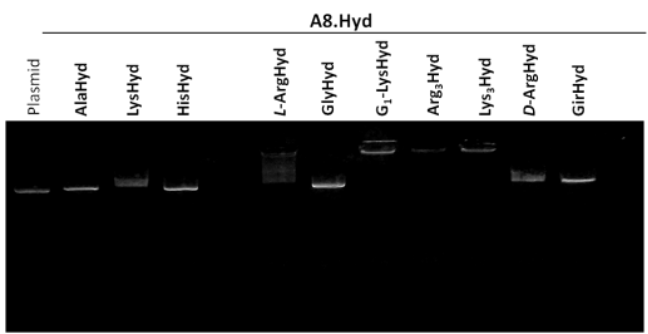

Fig. 9 Gel electrophoresis analysis showing the complexation of plasmid DNA by clusters made of scaffold $\mathbf{A} 8$ with different hydrazides. Experiments carried out at $\mathrm{N} / \mathrm{P}=40$.

The absence of DNA complexation observed by gel electrophoresis with amino acids of low pKa (His, Lys) is in contrast with the $\mathrm{EthBr}$ assay but is most likely explained by $\mathrm{pH}$ effects since the former was carried out at $\mathrm{pH} 8.0$ while the latter was carried out at $\mathrm{pH}$ 5.0.24

The screening results also show that the amino acids bearing no positive charges on their side groups, such as GlyHyd and AlaHyd, do not yield potent DNA binders when assembled onto the tetravalent scaffold $\mathbf{A} \mathbf{8}$, thereby indicating that the presentation of $\alpha$ amino groups is not sufficient for promoting DNA binding. Nevertheless, when tested at $N / P=80$ by the EthBr assay ( $\mathrm{pH}$ 5.0), DNA complexation with cluster A8.Gly can be detected. The comparison of DNA complexation properties with cluster A8.L-Arg shows that, while the latter does complex DNA effectively at low $N / P=2$ and high salinity (150 mM NaCl), the former only binds DNA at high $N / P=80$ and low salinity (9.4 $\mathrm{mM} \mathrm{NaCl}$ ) (Table 1$)$. 
Table 1 ctDNA complexation, assessed by fluorescence displacement assay, by clusters A8.L-Arg and A8.Gly in different conditions.

\begin{tabular}{ccccc}
\hline Entry & Compounds & $\mathrm{N} / \mathrm{P}^{[\mathrm{a}]}$ & $\begin{array}{c}{[\mathrm{NaCl}]} \\
(\mathrm{mM})\end{array}$ & $\begin{array}{c}\text { Fluorescence } \\
\text { Emission }(\%)^{[\mathrm{b}]}\end{array}$ \\
\hline 1 & A8.L-Arg & 80 & 9.4 & 2.6 \\
2 & A8.L-Arg & 2 & 9.4 & 0 \\
3 & A8.L-Arg & 80 & 150 & 25.3 \\
4 & A8.Gly & 80 & 9.4 & 3.6 \\
5 & A8.Gly & 2 & 9.4 & 100 \\
6 & A8.Gly & 80 & 150 & 92.4 \\
\hline
\end{tabular}

[a] N/P represents the ratio of positive charges $(N)$ per phosphodiester $(P)$; [b] measured after 20 hours.

Gel retardation assays $(\mathrm{pH}$ 8.0) support this conclusion by showing no DNA complexation with cluster A8.Gly in the range of N/P = 10-80 while cluster A8.L-Arg clearly complexes DNA at $\mathrm{N} / \mathrm{P} \geq 20$ (see $\mathrm{SI}) .^{18}$

We were intrigued by the apparent differences in DNA-binding ability between clusters A8.L-Arg and A8.D-Arg (Fig. 9). A cross-analysis by gel electrophoresis at different N/P confirms that, indeed, the chirality of the binding group has a strong influence over the DNA-binding ability of the corresponding clusters (Fig. 10). With cluster A8.D-Arg, the gel retardation assay shows, in the range of N/P $=10-100$, the appearance of a band slightly above the band of plasmid DNA. Compared to the results obtained with cluster A8.L-Arg, this suggests a weaker DNA complexation and most probably indicates different structures of the complexes with DNA. Again, this result suggests that long-range electrostatic interactions are not the sole responsible for the interactions between such cationic biomolecular clusters and DNA.

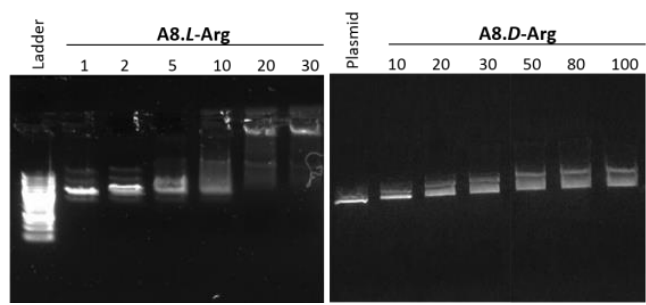

Fig. 10 Gel electrophoresis analyses showing the complexation of plasmid DNA by clusters A8.D-Arg (right) compared to A8.L-Arg (left) at different N/P.

Overall, the fragments screening methodology enabled the rapid and successful identification of clusters that effectively bind DNA. The combination between the pre-organized scaffold A8 and hydrazide binding groups featuring Larginine(s) leads to the most effective complexation of DNA.

\section{Biological evaluation.}

The potential of clusters A.Hyd as siRNA vectors was then evaluated on a MCF7-luc cell line which is derived from MCF7 human breast cancer cells transfected by firefly luciferase gene. We first studied the cluster A8.L-Arg. Although dynamic light scattering (DLS) experiments confirm complex formation with siRNA and indicate a particle diameter of $148-190 \mathrm{~nm}$ at $\mathrm{N} / \mathrm{P}=20$, no significant evidence of cell penetration and transfection efficacy were observed by, respectively, fluorescence imaging and cell luciferase assay (data not shown). We then turned our attention to the more effective cluster, A8.Arg. Gel retardation assay confirms complex formation with siRNA at N/P $\geq 9$ (Fig. 11).

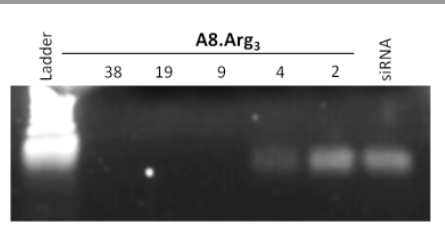

Fig. $11 \mathrm{Gel}$ electrophoresis analyses showing the complexation of siRNA by cluster A8. $\operatorname{Arg}_{3}$ at different N/P.

Similarly, DLS also shows complex formation with siRNA at $\mathrm{N} / \mathrm{P}=9$. The particles that are formed have diameter around $200 \mathrm{~nm}$ (PDI=0.1-0.2) and show good stability over time. In physiological salt concentration, the particles have a hydrodynamic diameter of $320 \mathrm{~nm}$ (PDI=0.17) (Table 2).

Table 2 Particle size characterization by dynamic light scattering of the complex formed between cluster $\mathbf{A} 8 . \mathbf{A r g}_{3}$ and siRNA at N/P=9. Results are expressed as mean \pm standard deviation $(n=3)$.

\begin{tabular}{cccc}
\hline & to & After 1 hour & $\begin{array}{c}\text { After 1 hour } \\
(154 \mathrm{mM} \mathrm{NaCl})\end{array}$ \\
\hline Z-average $^{[\mathrm{a}]}$ & $179.3 \pm 1.2$ & $201.8 \pm 1.9$ & $320.4 \pm 30.0$ \\
PDI $^{[\mathrm{b}]}$ & $0.143 \pm 0.005$ & $0.154 \pm 0.009$ & $0.122 \pm 0.008$ \\
\hline
\end{tabular}

[a] hydrodynamic diameter in $\mathrm{nm}$; [b] polydispersity index

Then, the internalization of these particles by the cancer cells was analysed by fluorescent microscopy. Satisfyingly, the fluorescence imaging carried out with a Cy3-labeled noncoding siRNA shows that the cluster $\mathbf{A 8 . A r g}_{3}$ effectively transfects siRNA inside MCF7 cells (Fig. 12). This conclusion was confirmed on another breast cancer cell line, MDA-MB231 (see SI).

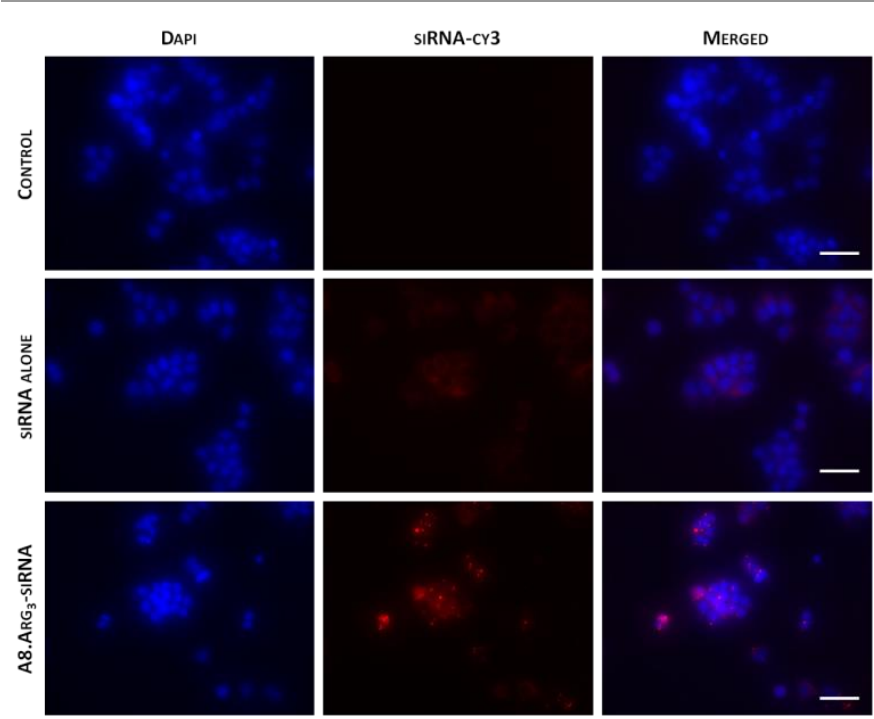

Fig. 12 Fluorescence imaging (magnification 40x) of MCF7 cells, alone (top), with Cy3labeled non-coding siRNA (middle), and with the complex formed between cluster A8. $^{-A r g_{3}}$ and Cy3-labeled non-coding siRNA at N/P=9 (bottom). The blue fluorescence 
(left) indicates the nuclei (DAPI staining), and red fluorescence (middle) indicates the Cy3-labeled siRNA. Bars represent $50 \mu \mathrm{m}$

The luciferase assay carried out with the 21-mer siRNA targeting the expression of luciferase further shows that the

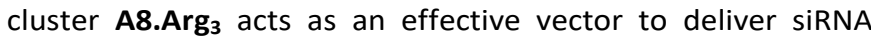
inside cells at $N / P=9$. A dose-dependent silencing of the expression of luciferase was observed by fluorescence spectroscopy with increasing amounts of siRNA being transfected (Fig. 13). The cell viability was assessed by a MTT assay and shows no significant cell toxicity up to $0.5 \mu \mathrm{M}$ of cluster A8.Arg 3 (Fig. 13). These results show that there is a range of concentration (0.1-0.5 $\mu \mathrm{M}$ siRNA) where the cluster A8. Arg $_{3}$ shows good transfection efficacy and no cellular toxicity.
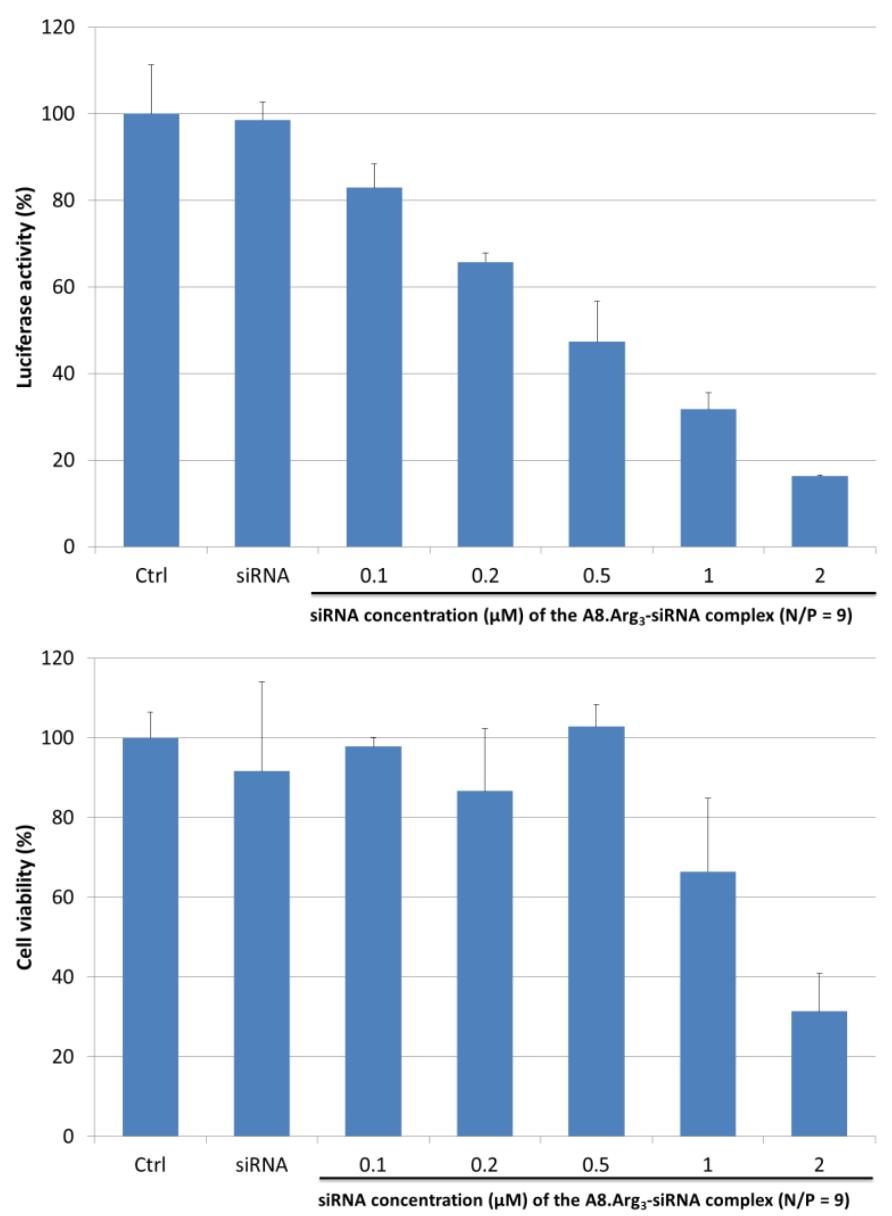

Fig. 13 Luciferase activity (top) and MTT cell viability (bottom) assays showing respectively, the transfection of a 21-mer siRNA targeting the expression of luciferase inside MCF7-luc, and the viability of those cells. The experiments were carried out with increasing amounts of siRNA (0.1 to $2 \mu \mathrm{M}$ ) contained in the $\mathbf{A 8 .} \mathbf{A r g}_{3}$ :siRNA complex $(\mathrm{N} / \mathrm{P}=9)$. The results are expressed as mean \pm standard deviation $(n=3)$.

\section{Conclusions}

We reported herein a rapid screening methodology for determining the DNA-binding ability of various clusters formed by acylhydrazone ligations. The results show that the structure of the scaffold has a profound impact on the multivalent recognition of DNA. Furthermore, the detailed role of binding group structure and chirality has been evidenced. The potential of these clusters was then evaluated on cell culture and it was found that the most potent DNA-binding cluster also complexes, transports, and delivers effectively siRNA inside cells without displaying significant toxicity. The results pave the way towards the application of these biomolecular clusters as artificial vectors for the transport of oligonucleotides of therapeutic interest. Further chemical modifications of the hits identified herein will be studied in order to optimize the transfection efficacy by, for instance, attaching lipophilic tails. ${ }^{25}$

\section{Experimental}

Materials and methods.

All solvents and chemical reagents were purchased from commercial suppliers and used without further purifications. Dry solvents were purchased in anhydrous quality from Fisher Scientific (Acros). For dichloromethane, amylene was the stabilizer. Calf-thymus DNA (ctDNA) was purchased from Sigma Aldrich.

NMR. NMR spectra were recorded on Bruker Avance 400 instruments and were referenced with respect to the residual solvent peak. Data are reported as follows: chemical shift ( $\delta$ in $\mathrm{ppm}$ ), multiplicity ( $\mathrm{s}$ for singlet, $\mathrm{d}$ for doublet, $\mathrm{t}$ for triplet, $\mathrm{q}$ for quadruplet, $\mathrm{m}$ for multiplet, bs for broad signal), coupling constant ( $\mathrm{J}$ in Hertz) and integration.

Mass spectrometry. MALDI-TOF and high resolution mass spectrometry analyses were carried out at the Laboratoire de Mesures Physiques, IBMM, Université de Montpellier, and were obtained, respectively, on an Ultraflex III and a Waters MicromassQ ToF mass spectrometer (positive mode).

HPLC. HPLC analyses were performed on a Waters HPLC 2695 (EC Nucleosil 300-5 C18, (125 × $3 \mathrm{~mm}$ ) column, MachereyNagel) equipped with a Waters 996 DAD detector. The following linear gradients of solvent B (acetonitrile) into solvent A (100 mM triethylammonium acetate/acetonitrile 95/5) were used: 0 to $95 \%$ of solvent B in 45 min. Retention times $\left(t_{R}\right)$ are given in minutes. Semi-preparative RP-HPLC was performed on a Waters 515 HPLC (VP Nucleodur HTec C18, 7 $\mu \mathrm{m},(250 \times 21)$ column, Macherey-Nagel) equipped with a Waters 2487 detector. Preparative HPLC was performed on a Waters Prep LC Controller HPLC (XSelect CSH Prep C18, $5 \mu \mathrm{m}$, $(250 \times 30 \mathrm{~mm})$ column, Macherey-Nagel) equipped with a Waters 2489 detector.

SPPS. Solid-phase peptide synthesis (SPPS) was carried out on a Liberty, $\mathrm{CEM}^{\odot}$ instrument equipped with microwave. The following conditions were used:

Solid support: 2-Chlorotrityl chloride resin.

Coupling conditions: Fmoc-AA-OH (3 eq.), HBTU (3 eq.), DIEA (5 eq.), DMF, $70^{\circ} \mathrm{C}$ for $5 \mathrm{~min}$ with microwave irradiation $(0.25$ mmol scale: $40 \mathrm{~W}, 0.1 \mathrm{mmol}$ scale: $23 \mathrm{~W}$ ). Double coupling (7 min) was used for arginine. In order to prevent diketopiperazine formation, the coupling of the amino acids next to Pro-Gly sequence was performed without heating or microwaves. 
Deprotection conditions: Piperidine/DMF (2/8). $75^{\circ} \mathrm{C} / 40 \mathrm{~W}$ for $30 \mathrm{sec}$, then $70^{\circ} \mathrm{C} / 45 \mathrm{~W}$ for $3 \mathrm{~min}$ (twice).

Cleavage conditions: TFA/ $\mathrm{CH}_{2} \mathrm{Cl}_{2}$ (1/99), then $\mathrm{MeOH} /$ Pyridine (8/2).

Fluorescence displacement assay. Ethidium Bromide displacement assays were carried out either in cuvettes $(3 \mathrm{~mL}$ quartz cuvette for experiments with $\mathrm{N} / \mathrm{P}=80,0.5 \mathrm{~mL}$ quartz cuvette for experiments with $\mathrm{N} / \mathrm{P}=2$ ) on a Hitashi Fluorescence Spectrophotometer F-2500, or in COSTAR 96-Well plates on a SAFAS Monaco Xenius XML instrument. Excitation wavelength was set at $546 \mathrm{~nm}$ and emission was measured at $590 \mathrm{~mm}$. The relative fluorescence emission decrease was calculated as follows:

$$
\text { Fluorescence emission decrease }(\%)=\left(\frac{I_{\mathrm{EthBr}-\mathrm{DNA}}-\mathrm{I}}{\mathrm{I}_{\mathrm{EthBr}-\mathrm{DNA}}-\mathrm{I}_{\mathrm{EthBr}}}\right)
$$

where $I_{\text {EthBr-DNA }}$ represents the fluorescence emission of the EthBr-ctDNA intercalation complex, I represents the measured fluorescence emission, and $I_{E t h B r}$ represents the fluorescence emission of EthBr in the absence of ctDNA.

The samples were prepared in the following buffers: i) sodium acetate $(100 \mathrm{mM}, \mathrm{pH} 5.0)$, EDTA $(10 \mu \mathrm{M}), \mathrm{NaCl}(9.4 \mathrm{mM})$, or ii) Hepes buffer (100 mM, pH 7.2), EDTA $(10 \mu \mathrm{M}), \mathrm{NaCl}(9.4 \mathrm{mM})$, or iii) sodium acetate $(100 \mathrm{mM}, \mathrm{pH} 5.0)$, EDTA $(10 \mu \mathrm{M}), \mathrm{NaCl}$ (150 mM).

Experiments in cuvette format were carried out as follows: Ethidium bromide was dissolved in the buffer to provide 42 $\mu \mathrm{M}$ concentration and the fluorescence was measured. The appropriate amount of ctDNA was added from a stock solution in MilliQ $\mathrm{H}_{2} \mathrm{O}$ to reach the desired N/P. The ligands were then added in microliters from $20-500 \mathrm{mM}$ stock solutions in Millia $\mathrm{H}_{2} \mathrm{O}$ to provide a final concentration of $1 \mathrm{mM}$ in scaffold. The fluorescence measurement was recorded after shaking the solution a few seconds.

Experiments in 96-well plates were carried out as follows:

Scaffolds A (20 mM) and hydrazide building blocks Hyd (160 $\mathrm{mM}$ ) were mixed in MilliQ $\mathrm{H}_{2} \mathrm{O}$, in each well, and left overnight at room temperature. Buffer, ctDNA, and $\mathrm{EthBr}$ were then added (final concentration in scaffold: $1 \mathrm{mM}$ ). The plates was shaken by orbital agitation (16 Hz, $120 \mathrm{sec}$ ), and the fluorescence emission was measured during $1 \mathrm{sec}$ using a 1200 $\checkmark$ voltage and a bandwidth of $6 \mathrm{~nm}$ for excitation and $10 \mathrm{~nm}$ for emission.

Gel electrophoresis. Gel retardation assays with plasmid DNA were performed using $100 \mathrm{ng}$ of 5.7 kilobase pair expression vector pET-15b (Novagen), which were mixed with the appropriate amounts of ligand (in order to reach the desired $\mathrm{N} / \mathrm{P}$ ratio) in 0.5X TAE (20 mM Tris-acetate/0.5 mM EDTA, $\mathrm{pH}$ 8.0) or 0.5X TBE (20 mM Tris-borate/0.5 mM EDTA, pH 8.0) buffer to obtain a final volume of $10 \mu \mathrm{L}$. $2 \mu \mathrm{L}$ of Blue $6 \mathrm{X}$ loading dye (Fisher Scientific) was added, after which $12 \mu \mathrm{L}$ was run on a $0.7 \%$ agarose gel ( $50 \mathrm{~V}$ ). DNA was visualized with SYBER Safe (Life Technologies) or SafeView Plus ${ }^{\mathrm{TM}}$ Nucleic Acid Stain (Euromedex). The reference for the gel is GeneRuler $1 \mathrm{~kb}$ DNA ladder (250 to $10000 \mathrm{bp})$ from Fischer Scientific. Gel retardation assays with siRNA were performed as follows: the cluster:siRNA complexes at a desired N/P were prepared in RNase free water with $300 \mathrm{ng}$ of eGFP siRNA. Electrophoresis was carried out on a $1 \% \mathrm{wt} / \mathrm{vol}$ agarose gel in $1 \times$ TBE at $55 \mathrm{~V}$ for $1 \mathrm{~h}$. The GelRed-stained siRNA was visualized on an ultraviolet transilluminator with a camera.

Dynamic light scattering. Particle size measurements were carried out on a Zetasizer Nano ZS (Malvern, United Kingdom) with transparent ZEN0040 disposable microcuvette cells (40 $\mu \mathrm{l})$ at $25^{\circ} \mathrm{C}$. The cluster:siRNA complexes were prepared at a defined N/P ratio with a siRNA concentration of $1 \mu \mathrm{M}$. Measurements were performed immediately after the complexes formation and after $1 \mathrm{~h}$ incubation. Then, $\mathrm{NaCl}$ solution was added at a final concentration of $154 \mathrm{mM}$ and measurement was repeated.

Biological evaluation on cell culture. The MCF7-luc cell line derived from MCF7 human breast cancer cells by stable transfection of firefly luciferase gene (PCDNA 3.1 CMV-LucSVNeo) were generously provided by $\mathrm{Dr}$ P. Balaguer (ICM Montpellier, France). Selection of resistant clones was performed by geneticin addition at $1 \mathrm{mg} \cdot \mathrm{mL}^{-1}$ until experiments. Cells were grown in phenol red-free F12/ Dulbecco's modified Eagle's medium (DMEM) supplemented with $10 \%$ fetal calf serum (FCS). The cells were incubated at $37^{\circ} \mathrm{C}$ in a humidified atmosphere with $5 \% \mathrm{CO}_{2}$.

Cy3-labeled non-coding siRNA was purchased from Eurogentec (Serring, Belgium). The siRNA targeting sequence for luciferase (AACTTACGCTGAGTACTTCGA) was purchased from QIAGEN. The sense sequence is CUUACGCUGAGUACUUCGA and the antisense sequence is UCGAAGUACUCAGCGUAAG.

The MTT (3-(4,5-dimethyl-thiazol-2-yl)-2,5-diphenyltetrazolium bromide, a yellow tetrazole) assay kit was purchased from Sigma-Aldrich (Saint-Quentin-Fallavier, France).

The cluster:siRNA complexes were prepared as follows: the clusters A.Hyd (20 mM in filtered RNase-free water) were vortexed for $5 \mathrm{~s}$, ultrasonically mixed for $5 \mathrm{~min}$, mixed with siRNA in order to reach the desired $\mathrm{N} / \mathrm{P}$, and incubated at room temperature for $20 \mathrm{~min}$.

Fluorescence microscopy. MCF7-luc cells were seeded at a density of 50,000 cells per well and incubated for $24 \mathrm{~h}$ in a 8 well tissue culture chambers (Sarstedt, Germany) before

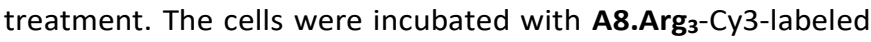
siRNA complexes at a molar ratio of $25 / 1(N / P=9)$ in OptiMEM (Invitrogen) for $4 \mathrm{~h}$. These cells were then fixed with $500 \mu \mathrm{l}$ of cold $4 \%$ PFA for $30 \mathrm{~min}$ and washed twice with PBS. The nuclei were stained using a DAPI solution (Sigma-Aldrich, Saint Quentin-Fallavier, France). Images were taken with an inverted fluorescence microscope (Leica DMRB, Leica Microsystems $\mathrm{GmbH}$, Germany) and analyzed using ImageJ software.

Cell luciferase assay. MCF7-luc cells were seeded at a density of 5000 cells per well in 96-well white opaque tissue culture plates in $150 \mu \mathrm{l}$ complete culture medium and incubated for 24 h. The cells were then washed with PBS and incubated with various cluster:siRNA complex formulations in OptiMEM at $37^{\circ} \mathrm{C}$ for $4 \mathrm{~h}$. Thereafter, $50 \mu \mathrm{l}$ of $40 \%$ serum containing medium was added. Two days after transfection, expression of luciferase was assessed by addition into culture medium of luciferin $\left(10^{-3} \mathrm{M}\right.$, final concentration) purchased from Promega (France). Living cell luminescence was measured $10 \mathrm{~min}$ after by a multilabel plate reader (Wallac1420, PerkinElmer, USA) 
for 5 s. Values are expressed as percentage of luciferase activity compared to non-treated wells (set as $100 \%$ ).

Cytotoxicity assay. The cytotoxicity of cluster:siRNA complexes was determined by the MTT assay. In brief, MCF7-luc cells were seeded at 5,000 cells/well in clear, flat-bottomed, 96-well plates (Costar) $24 \mathrm{~h}$ before treatment. After being washed, 150 $\mu \mathrm{l}$ of OptiMEM that contained the cluster:siRNA complexes at different N/P ratios was added to the wells and incubated for 4 h. Thereafter, $50 \mu \mathrm{l}$ of $40 \%$ serum containing medium was added, and the cytotoxicity of the relevant reagents was determined by the MTT assay after $48 \mathrm{~h}$. The absorbance at $540 \mathrm{~nm}$ was read on a plate reader (Multiskan FC, Thermo Fisher Scientific, France). The results obtained from triplicate wells were averaged and normalized to the value obtained from the non-treated cells.

\section{Synthetic procedures.}

Linear peptide A7. Similarly to the synthesis of cyclic peptide A8, ${ }^{18}$ the decapeptide was synthesized via SPPS strategy $(0.25$ mmol scale) using 2-Chlorotrityl Chloride resin and a FmocLys[Boc-Ser $(t-B u)]-O^{26}$ dipeptide. The resin was loaded with the first amino acid by reacting $3 \mathrm{~g}(4.8 \mathrm{mmol} / \mathrm{Cl})$ of resin with $4.3 \mathrm{~g}$ (14.4 mmol, 3eq) of Fmoc-Gly-OH and $4.2 \mathrm{~mL}(24 \mathrm{mmol}$, $2 \mathrm{M}, 5$ eq) of DIEA in $40 \mathrm{~mL}$ DMF/dichloromethane for 1.5 hour. The resin was then filtered, washed with $\mathrm{MeOH}, \mathrm{DMF}(3 \mathrm{x})$, $\mathrm{CH}_{2} \mathrm{Cl}_{2}(2 \mathrm{x})$, diethyl ether (1x) and dried in vacuo. The loading was quantified by UV-Vis spectroscopy ${ }^{27}$ as follows: $10 \mathrm{mg}$ of resin were suspended in $1 \mathrm{~mL}$ of Piperidine/DMF (2/8) for 20 min and filtered. $100 \mu \mathrm{L}$ of the filtrate were dissolved in $10 \mathrm{~mL}$ of DMF and the absorbance was measured at $301 \mathrm{~nm}$. The charge of the modified resin was determined to be 0.31 $\mathrm{mmol} / \mathrm{g}$, and it was then engaged in SPPS. The final acetylation was then carried out with $10 \mathrm{~mL}$ of a solution of acetic anhydride $/ \mathrm{CH}_{2} \mathrm{Cl}_{2}(50 / 50)$ for $20 \mathrm{~min}(2 \mathrm{x})$. The product was then cleaved and deprotected with a TFA/ $\mathrm{H}_{2} \mathrm{O} / \mathrm{TIS}(95 / 2.5 / 2.5)$ solution $(20 \mathrm{~mL})$ for 2 hours. The filtrate was concentrated, precipitated by adding $\mathrm{Et}_{2} \mathrm{O}$, and centrifuged (10000 t/min for $10 \mathrm{~min}$ ). The supernatant was removed and the crude material was freeze dried to give a white solid (326 mg, 71\%). The oxidative cleavage was carried out by dissolving the crude material in $18.4 \mathrm{~mL}$ of $\mathrm{H}_{2} \mathrm{O}$ and adding $403 \mathrm{mg}(1.8 \mathrm{mmol}, 10$ eq) of sodium periodate. The desired product was then purified by semi-preparative HPLC using the following gradient of ACN/TFA 99.9/0.1 into $\mathrm{H}_{2} \mathrm{O}: 0$ to $25 \%$ in $25 \mathrm{~min}$, then $25 \%$ to $100 \%$ in $10 \mathrm{~min} .104 \mathrm{mg} \mathrm{(47 \% )}$ of a white solid were obtained (overall yield for the preparation of A7: 51\%). HPLC: $t_{R} 3.49$ min; MALDI-ToF (HCCA): calcd for $\left[\mathrm{C}_{54} \mathrm{H}_{82} \mathrm{~N}_{14} \mathrm{O}_{20}+\mathrm{K}\right]^{+} 1285.58$, found 1285.52 .

General procedure for the solid-phase synthesis of amino acid hydrazides. Preparation of the modified resin: DIEA $(2.45$ $\mathrm{mL}, 14.05 \mathrm{mmol}$ ) was added to a suspension of 2-Chlorotrityl Chloride resin $(1.75 \mathrm{~g}, 2.81 \mathrm{mmol} \mathrm{Cl} / \mathrm{g})$ in NMP/DMSO (4/1) (9 $\mathrm{mL}$ ). A solution of 9-Fluorenylmethyl carbazate (Fmochydrazide, $2.14 \mathrm{~g}, 8.43 \mathrm{mmol})$ in DMSO $(9 \mathrm{~mL})$ was then added and the mixture was stirred for 2 hours. After filtration, capping was performed by mixing with $\mathrm{MeOH}$ for a few minutes. The resin was then filtered, washed with DMSO (3x), $\mathrm{CH}_{2} \mathrm{Cl}_{2}(2 \mathrm{x})$, isopropanol (1x), $\mathrm{CH}_{2} \mathrm{Cl}_{2}(2 \mathrm{x})$ and $\mathrm{Et}_{2} \mathrm{O}(3 \mathrm{x})$, and dried in vacuo. The loading, calculated according to the procedure used in the synthesis of $\mathbf{A 7}$, was determined to be $0.39 \mathrm{mmol} / \mathrm{g}$.

Peptide couplings procedure: The initial Fmoc deprotection was carried out as follows: the resin was suspended in a solution of Piperidine/NMP/DMSO (30/56/14) ( $2 \mathrm{~mL}$ ). After $1 \mathrm{~h}$, it was filtered, washed with DMSO (3x), $\mathrm{CH}_{2} \mathrm{Cl}_{2}$ (2x), Isopropanol (1x), $\mathrm{CH}_{2} \mathrm{Cl}_{2}(2 \mathrm{x}), \mathrm{Et}_{2} \mathrm{O}(3 \mathrm{x})$, and dried in vacuo. The resin (500 $\mathrm{mg}, 0.195 \mathrm{mmol}$ ) was suspended in a solution of NMP/DMSO (4/1) (500 $\mu \mathrm{L})$. The Fmoc-Amino acid-OH (0.351 $\mathrm{mmol})$ was pre-activated by addition, in a solution of NMP/DMSO (4/1) (1 mL), of DIEA (98 $\mu \mathrm{L}, 0.585 \mathrm{mmol})$ and HATU (133.5 mg, $0.351 \mathrm{mmol})$. After $30 \mathrm{~min}$, the mixture of pre-activated amino acid was added to the resin. After 3 hours, the resin was filtered and this coupling procedure was repeated twice. The resin was then washed (DMSO (3x), $\mathrm{CH}_{2} \mathrm{Cl}_{2}$ (2x), Isopropanol (1x), $\mathrm{CH}_{2} \mathrm{Cl}_{2}(2 \mathrm{x})$ and $\mathrm{Et}_{2} \mathrm{O}(3 \mathrm{x})$ ) and dried. Capping was carried out by suspending the resin in a solution of acetic anhydride $/ \mathrm{CH}_{2} \mathrm{Cl}_{2}(1 / 1)(2 \mathrm{~mL})$ for $20 \mathrm{~min}$ (procedure repeated twice). The resin was then filtered, washed (DMSO (3x), $\mathrm{CH}_{2} \mathrm{Cl}_{2}(2 \mathrm{x})$, Isopropanol (1x), $\mathrm{CH}_{2} \mathrm{Cl}_{2}(2 \mathrm{x})$ and $\mathrm{Et}_{2} \mathrm{O}(3 \mathrm{x})$ ) and dried in vacuo. Fmoc deprotection was carried out by suspending the resin in a solution of Piperidine/NMP/DMSO $(30 / 56 / 14)$ ( $2 \mathrm{~mL}$ ) for 1 hour. The resin was then filtered, washed and dried in vacuo.

Deprotection and cleavage procedure: The resin was suspended in a solution of TFA/TIS/ $\mathrm{H}_{2} \mathrm{O}(95 / 2.5 / 2.5)(5 \mathrm{~mL})$ for 2 hours, then filtered and washed with $\mathrm{CH}_{2} \mathrm{Cl}_{2}$. The filtrate was partially concentrated in vacuo, and precipitated with $\mathrm{Et}_{2} \mathrm{O}$. After centrifugation and removal of the supernatant, the white solid was freeze dried.

2-aminoacetohydrazide (GlyHyd). GlyHyd was synthesized according general procedure (60.6 mg, quantitative). ${ }^{1} \mathrm{H} \mathrm{NMR}$ $\left(\mathrm{D}_{2} \mathrm{O} ; 400 \mathrm{MHz}\right) \delta 3.88\left(\mathrm{~s}, 2 \mathrm{H}, \mathrm{H}_{2} \mathrm{~N}-\mathrm{CH}_{2}\right) ;{ }^{13} \mathrm{C} \mathrm{NMR}\left(\mathrm{D}_{2} \mathrm{O} ; 100\right.$ $\mathrm{MHz}) \delta 166.0,163.1$ (q, $\left.{ }^{2} \mathrm{~J}(\mathrm{C}, \mathrm{F})=35,1 \mathrm{C}, \mathrm{F}_{3} \mathrm{C}-\mathrm{C}=\mathrm{O}\right), 117.8$ (q, $\left.1 \mathrm{~J}(\mathrm{C}, \mathrm{F})=290,1 \mathrm{C}, \mathrm{F}_{3} C-\right), 39.2$.

(S)-2-aminopropanehydrazide (AlaHyd). AlaHyd was synthesized according general procedure $(21.2 \mathrm{mg}, 67 \%) .{ }^{1} \mathrm{H}$ NMR $\left(\mathrm{D}_{2} \mathrm{O} ; 400 \mathrm{MHz}\right) \delta 4.19\left(\mathrm{q},{ }^{2} \mathrm{~J}=7.0,1 \mathrm{H}, \mathrm{H}_{2} \mathrm{~N}-\mathrm{CH}\right), 1.57(\mathrm{~d}$, $\left.{ }^{2} \mathrm{~J}=7.0,3 \mathrm{H}, \mathrm{CH}-\mathrm{CH}_{3}\right) ;{ }^{13} \mathrm{C} \mathrm{NMR}\left(\mathrm{D}_{2} \mathrm{O} ; 100 \mathrm{MHz}\right) \delta 169.2,163.1$ (q, $\left.\left.{ }^{2} \mathrm{~J}(\mathrm{C}, \mathrm{F})=35,1 \mathrm{C}, \mathrm{F}_{3} \mathrm{C}-\mathrm{C}=\mathrm{O}\right), 117.8\left(\mathrm{q},{ }^{1} \mathrm{~J}(\mathrm{C}, \mathrm{F})=290,1 \mathrm{C}, \mathrm{F}_{3} \mathrm{C}-\right)\right), 47.9$, $16.2 ;[\alpha]_{D}^{20}: \quad+8.1 \quad\left(\mathrm{H}_{2} \mathrm{O}, \quad \mathrm{c}=1.0\right) ; \quad \mathrm{HR}-\mathrm{ESI}-\mathrm{MS}:$ calcd for $\left[\mathrm{C}_{3} \mathrm{H}_{9} \mathrm{~N}_{3} \mathrm{O}+\mathrm{H}\right]^{+}$104.0824, found 104.0822.

(S)-3-amino-4-hydrazinyl-4-oxobutanoic acid (AspHyd). AspHyd was synthesized according general procedure (19.2 $\mathrm{mg}, 53 \%) .{ }^{1} \mathrm{H}$ NMR $\left(\mathrm{D}_{2} \mathrm{O} ; 400 \mathrm{MHz}\right) \delta 4.43\left(\mathrm{~m}, 1 \mathrm{H}, \mathrm{CH}-\mathrm{CH}_{2}\right)$, $3.08\left(\mathrm{~m}, 2 \mathrm{H}, \mathrm{CH}-\mathrm{CH}_{2}-\mathrm{CO}\right) ;{ }^{13} \mathrm{C}$ NMR $\left(\mathrm{D}_{2} \mathrm{O} ; 100 \mathrm{MHz}\right) \delta 172.3$, 167.3, 163.1 (q, $\left.{ }^{2} J(C, F)=35,1 C, F_{3} C-C=0\right), 117.8(q, 1 J(C, F)=290$, $\left.1 C, \mathrm{~F}_{3} \mathrm{C}-\right), 48.5,34.6 ;[\alpha]_{\mathrm{D}}^{20}:+17.4\left(\mathrm{H}_{2} \mathrm{O}, \mathrm{c}=1.0\right)$; HR-ESI-MS: calcd for $\left[\mathrm{C}_{4} \mathrm{H}_{9} \mathrm{~N}_{3} \mathrm{O}_{3}+\mathrm{H}\right]^{+} 148.0722$, found 148.0720 .

(S)-2-amino-3-(1H-imidazol-5-yl)propanehydrazide (HisHyd). HisHyd was synthesized according general procedure $(26.1 \mathrm{mg}$, $68 \%) .{ }^{1} \mathrm{H}$ NMR ( $\left.\mathrm{D}_{2} \mathrm{O} ; 400 \mathrm{MHz}\right) \delta 8.72(\mathrm{~s}, 1 \mathrm{H}, \mathrm{HN}-\mathrm{CH}=\mathrm{N}), 7.46(\mathrm{~s}$, $1 \mathrm{H}, \mathrm{C}=\mathrm{CH}-\mathrm{N}), 4.36\left(\mathrm{t},{ }^{3} \mathrm{~J}=7.0,1 \mathrm{H}, \mathrm{CH}-\mathrm{CH}_{2}\right) ;{ }^{13} \mathrm{C} \mathrm{NMR}\left(\mathrm{D}_{2} \mathrm{O} ; 100\right.$ $\mathrm{MHz}) \delta 166.6,163.1\left(\mathrm{q},{ }^{2} \mathrm{~J}(\mathrm{C}, \mathrm{F})=35,1 \mathrm{C}, \mathrm{F}_{3} \mathrm{C}-\mathrm{C}=\mathrm{O}\right), 135.6,125.4$, 
118.6, $117.8\left(\mathrm{q},{ }^{1} \mathrm{~J}(\mathrm{C}, \mathrm{F})=290,1 \mathrm{C}, \mathrm{F}_{3} C-\right), 50.9,25.8 ;[\alpha]_{\mathrm{D}}^{20}:+18.0$ $\left(\mathrm{H}_{2} \mathrm{O}, \mathrm{c}=1.0\right)$; HR-ESI-MS: calcd for $\left[\mathrm{C}_{6} \mathrm{H}_{11} \mathrm{~N}_{5} \mathrm{O}+\mathrm{H}\right]^{+} 170.1042$ found 170.1041 .

(S)-2,6-diaminohexanehydrazide (LysHyd). LysHyd was synthesized according general procedure $(37.1 \mathrm{mg}, 84 \%) .{ }^{1} \mathrm{H}$ NMR $\left(\mathrm{D}_{2} \mathrm{O} ; 400 \mathrm{MHz}\right) \delta 4.08\left(\mathrm{t},{ }^{2} \mathrm{~J}=7.0,1 \mathrm{H}, \mathrm{H}_{2} \mathrm{~N}-\mathrm{CH}\right), 2.99(\mathrm{t}$, $\left.2 \mathrm{~J}=7.6,2 \mathrm{H}, \mathrm{CH}_{2}-\mathrm{NH}_{2}\right), 1.94\left(\mathrm{~m}, 2 \mathrm{H}, \mathrm{CH}_{2}-\mathrm{CH}_{2}-\mathrm{NH}_{2}\right), 1.70(\mathrm{~m}, 2 \mathrm{H}$, $\left.\mathrm{CH}-\mathrm{CH}_{2}\right) ;{ }^{13} \mathrm{C}$ NMR $\left(\mathrm{D}_{2} \mathrm{O} ; 100 \mathrm{MHz}\right) \delta 168.2,163.1$ (q, ${ }^{2} \mathrm{~J}(\mathrm{C}, \mathrm{F})=35$ 1C, $\mathrm{F}_{3} \mathrm{C}-\mathrm{C}=\mathrm{O}$ ), 117.8 (q, ${ }^{1} \mathrm{~J}(\mathrm{C}, \mathrm{F})=290,1 \mathrm{C}, \mathrm{F}_{3} \mathrm{C}-$ ) , 51.8, 39.0, 30.1, 26.3, 21.2; $[\alpha]_{D}^{20}:+16.8\left(\mathrm{H}_{2} \mathrm{O}, \mathrm{C}=1.0\right)$; HR-ESI-MS: calcd for $\left[\mathrm{C}_{6} \mathrm{H}_{16} \mathrm{~N}_{4} \mathrm{O}+\mathrm{H}\right]^{+}$161.1402, found 161.1402 .

\section{(S)-1-(4-amino-5-hydrazinyl-5-oxopentyl)guanidine}

ArgHyd). L-ArgHyd was synthesized according general procedure $(14.2 \mathrm{mg}, 81 \%) .{ }^{1} \mathrm{H}$ NMR $\left(\mathrm{D}_{2} \mathrm{O} ; 400 \mathrm{MHz}\right) \delta 4.10(\mathrm{t}$, $3 \mathrm{~J}=6.7,1 \mathrm{H}, \mathrm{CH}-\mathrm{CH}_{2}$ ), 3.24 (t, ${ }^{3} \mathrm{~J}=6.8,2 \mathrm{H}, \mathrm{CH}_{2}-\mathrm{CH}_{2}-\mathrm{NH}$ ), 2.02-1.92 (m, $\left.2 \mathrm{H}, \mathrm{CH}_{2}-\mathrm{CH}_{2}-\mathrm{NH}\right), 1.72-1.64\left(\mathrm{~m}, 2 \mathrm{H}, \mathrm{CH}-\mathrm{CH}_{2}-\mathrm{CH}_{2}\right) ;{ }^{13} \mathrm{C} \mathrm{NMR}$ $\left(\mathrm{D}_{2} \mathrm{O} ; 100 \mathrm{MHz}\right) \delta 168.2,156.8,51.6,40.2,27.7,23.5 ;[\alpha]_{\mathrm{D}} 20$. $+15.3\left(\mathrm{H}_{2} \mathrm{O}, \quad \mathrm{c}=1.0\right)$; HR-ESI-MS: calcd for $\left[\mathrm{C}_{6} \mathrm{H}_{16} \mathrm{~N}_{6} \mathrm{O}+\mathrm{H}\right]^{+}$ 189.1464, found 189.1466 .

(R)-1-(4-amino-5-hydrazinyl-5-oxopentyl)guanidine

$(D-$

ArgHyd). D-ArgHyd was synthesized according general procedure $(67.6 \mathrm{mg}, 75 \%) .{ }^{1} \mathrm{H}$ NMR $\left(\mathrm{D}_{2} \mathrm{O} ; 400 \mathrm{MHz}\right) \delta 4.15(\mathrm{t}$, $\left.3 \mathrm{~J}=6.6,1 \mathrm{H}, \mathrm{CHCH}_{2}\right), 3.24\left(\mathrm{t}, 3 \mathrm{~J}=6.8,2 \mathrm{H}, \mathrm{CH}_{2}-\mathrm{NH}\right), 2.02-1.95(\mathrm{~m}$, $\left.2 \mathrm{H}, \mathrm{CH}-\mathrm{CH}_{2}\right), 1.73-1.65\left(\mathrm{~m}, 2 \mathrm{H}, \mathrm{CH}_{2} \mathrm{CH}_{2} \mathrm{NH}\right) ;{ }^{13} \mathrm{C}$ NMR $\left(\mathrm{D}_{2} \mathrm{O} ; 100\right.$ $\mathrm{MHz}) \delta 168.1,163.1\left(\mathrm{q},{ }^{2} \mathrm{~J}(\mathrm{C}, \mathrm{F})=35,1 \mathrm{C}, \mathrm{F}_{3} \mathrm{C}-\mathrm{C}=\mathrm{O}\right), 156.9,117.8$ $\left(q, 1 J(C, F)=290,1 C, F_{3} C-\right), 51.6,40.3,27.8,23.5 ;[\alpha]_{D}{ }^{20}:-7.2$ $\left(\mathrm{H}_{2} \mathrm{O}, \mathrm{c}=1.0\right)$; HR-ESI-MS: calcd for $\left[\mathrm{C}_{6} \mathrm{H}_{16} \mathrm{~N}_{6} \mathrm{O}+\mathrm{H}\right]^{+}$189.1464, found 189.1464 .

(S)-2,6-diamino- $N$ - $((S)$-6-amino-1- $((S)$-6-amino-1-hydrazinyl1-oxohexan-2-yl)amino)-1-oxohexan-2-yl)hexanamide

(Lys ${ }_{3}$ Hyd). Lys ${ }_{3}$ Hyd was synthesized by SPPS on a $0.1 \mathrm{mmol}$ scale using the modified Fmoc hydrazine resin that is manually prepared from the 2-Chlorotrityl Chloride resin as described above. After SPPS, the product was cleaved from the resin with a solution of TFA $/ \mathrm{CH}_{2} \mathrm{Cl}_{2}(1: 99)(10 \mathrm{~mL})(3 \mathrm{~min}, 3 \mathrm{x})$. A solution of $\mathrm{MeOH} /$ Pyridine $(8 / 2)(10 \mathrm{~mL})$ was added to the filtrate and the solution was partially concentrated in vacuo. $\mathrm{Et}_{2} \mathrm{O}$ was added to the crude product and a white precipitate appeared. The mixture was centrifuged, the supernatant was removed and the precipitate was freeze dried. The crude product was then purified on preparative HPLC using the following gradient of ACN/TFA 99.9/0.1 into $\mathrm{H}_{2} \mathrm{O}: 20 \%$ to $40 \%$ in 20 min to obtain a white solid after freeze-drying. Final deprotection was carried out with TFA/ $\mathrm{H}_{2} \mathrm{O} / \mathrm{TIS}(95 / 2.5 / 2.5)(10 \mathrm{~mL})$ for 2 hours. The deprotected product was partially concentrated in vacuo. $\mathrm{Et}_{2} \mathrm{O}$ was then added and a white precipitate appeared. The mixture was centrifuged and the precipitate dried. $\mathbf{L y s}_{3} \mathbf{H y d}$ was freeze-dried and obtained as a white solid (49.3 $\mathrm{mg}, 52 \%$ ). ${ }^{1} \mathrm{H}$ NMR $\left(\mathrm{D}_{2} \mathrm{O} ; 400 \mathrm{MHz}\right) \delta 4.38-4.35\left(\mathrm{~m}, 2 \mathrm{H}, 2 \mathrm{CH}-\mathrm{CH}_{2}\right), 4.07(\mathrm{t}$, $\left.3 \mathrm{~J}=6.0,1 \mathrm{H}, \mathrm{CH}-\mathrm{CH}_{2}\right), 3.05-3.04\left(\mathrm{~m}, 6 \mathrm{H}, 3 \mathrm{CH}_{2}-\mathrm{NH}_{2}\right), 1.95-1.72(\mathrm{~m}$, $\left.12 \mathrm{H}, 3 \mathrm{CH}-\mathrm{CH}_{2}, 3 \mathrm{CH}_{2}-\mathrm{CH}_{2}-\mathrm{NH}_{2}\right), 1.55-1.45\left(\mathrm{~m}, 6 \mathrm{H}, 3 \mathrm{CH}-\mathrm{CH}_{2}-\mathrm{CH}_{2}\right)$; ${ }^{13} \mathrm{C}$ NMR $\left(\mathrm{D}_{2} \mathrm{O} ; 100 \mathrm{MHz}\right) \delta 173.6,171.8,169.7,163.1$ (q, $\left.{ }^{2} \mathrm{~J}(\mathrm{C}, \mathrm{F})=35,1 \mathrm{C}, \mathrm{F}_{3} \mathrm{C}-\mathrm{C}=\mathrm{O}\right), 117.8\left(\mathrm{q},{ }^{1} \mathrm{~J}(\mathrm{C}, \mathrm{F})=290,1 \mathrm{C}, \mathrm{F}_{3} C-\right.$ ) , 53.7, 52.8, 52.2, 39.2, 39.0, 30.6, 30.5, 30.3, 26.4, 26.3, 22.1, 22.0, 21.3; $[\alpha]_{D}^{20}:-11.6\left(\mathrm{H}_{2} \mathrm{O}, \quad \mathrm{c}=1.0\right)$; HR-ESI-MS: calcd for $\left[\mathrm{C}_{18} \mathrm{H}_{40} \mathrm{~N}_{8} \mathrm{O}_{3}+\mathrm{H}\right]^{+}$417.3302, found 417.3296.
(2S,2'S)-N,N'-((S)-6-hydrazinyl-6-oxohexane-1,5-diyl)bis(2,6diaminohexanamide) ( $\mathbf{G}_{1}$-LysHyd). $\mathbf{G}_{1}$-LysHyd was synthesized according to the general procedure for the solid-phase synthesis of amino acid hydrazides using Fmoc-L-Lys(Fmoc)$\mathrm{OH}$. The second coupling reaction was carried out with doubled quantities of reagents. Finally, the resin was suspended in a solution of TFA/TIS/ $\mathrm{H}_{2} \mathrm{O}(95 / 2.5 / 2.5)(5 \mathrm{~mL})$ for 2 hours, filtered and washed with $\mathrm{CH}_{2} \mathrm{Cl}_{2}$. The filtrate was partially concentrated in vacuo, and precipitated with $\mathrm{Et}_{2} \mathrm{O}$. After centrifugation and removal of the supernatant, the white solid was freeze dried to afford $\mathbf{G}_{1}$-LysHyd as a white solid (230.8 mg, 84\%). ${ }^{1} \mathrm{H} \mathrm{NMR}$ (MeOD; $400 \mathrm{MHz}$ ) $\delta 4.40$ (bs, $1 \mathrm{H}, \mathrm{CH}$ $\mathrm{CH}_{2}$ ), 3.96 (bs, $1 \mathrm{H}, \mathrm{CH}-\mathrm{CH}_{2}$ ), 3.85 (bs, $1 \mathrm{H}, \mathrm{CH}-\mathrm{CH}_{2}$ ), 3.25 (bs, $2 \mathrm{H}$, $\left.\mathrm{CH}_{2}-\mathrm{NH}\right), 2.95$ (bs, $\left.4 \mathrm{H}, 2 \mathrm{CH}_{2}-\mathrm{NH}\right), 1.89-1.47\left(\mathrm{~m}, 18 \mathrm{H}, 3 \mathrm{CH}-\mathrm{CH}_{2}-\right.$ $\mathrm{CH}_{2}, 3 \mathrm{CH}_{2}-\mathrm{CH}_{2}-\mathrm{CH}_{2}, 3 \mathrm{CH}_{2}-\mathrm{NH}_{2}$ ); ${ }^{13} \mathrm{C} \mathrm{NMR}$ (MeOD; $100 \mathrm{MHz}$ ) $\delta$ 170.2, 170.0, 54.3, 53.9, 53.6, 40.3, 40.3, 32.3, 32.1, 31.9, 29.8, 28.1, 28.0, 24.1, 22.9, 22.5; $[\alpha]_{\mathrm{D}} 20$ : $+8.8\left(\mathrm{H}_{2} \mathrm{O}, \mathrm{c}=1.0\right)$; HR-ESIMS: calcd for $\left[\mathrm{C}_{18} \mathrm{H}_{40} \mathrm{~N}_{8} \mathrm{O}_{3}+\mathrm{H}\right]^{+} 417.3302$, found 417.3299 .

(S)-2-amino-5-guanidino- $N-((S)-5$-guanidino-1-(( $(S)-5-$ guanidino-1-hydrazinyl-1-oxopentan-2-yl)amino)-1-

oxopentan-2-yl)pentanamide ( $\left.\mathrm{Arg}_{3} \mathrm{Hyd}\right) . \quad \mathrm{Arg}_{3} \mathrm{Hyd}$ was synthesized by SPPS on a $0.1 \mathrm{mmol}$ scale using the modified Fmoc hydrazine resin that is manually prepared from the 2Chlorotrityl Chloride resin as described above. After SPPS, the product was cleaved from the resin with a solution of TFA $/ \mathrm{CH}_{2} \mathrm{Cl}_{2}$ (1:99) $(10 \mathrm{~mL}) \quad(3 \mathrm{~min}, 3 x)$. A solution of $\mathrm{MeOH} /$ Pyridine $(8 / 2)(10 \mathrm{~mL})$ was added to the filtrate and the solution was partially concentrated in vacuo. $\mathrm{Et}_{2} \mathrm{O}$ was added to the crude product and a white precipitate appeared. The mixture was centrifuged, the supernatant was removed and the precipitate was freeze dried. The crude product was then purified on preparative HPLC using the following gradient of ACN/TFA 99.9/0.1 into $\mathrm{H}_{2} \mathrm{O}: 20 \%$ to $70 \%$ in 45 min to afford a white solid after freeze-drying. Final deprotection was carried out with TFA/ $\mathrm{H}_{2} \mathrm{O} / \mathrm{TIS}(95 / 2.5 / 2.5)(10 \mathrm{~mL})$ for 2 hours. The deprotected product was partially concentrated in vacuo and precipitated with $\mathrm{Et}_{2} \mathrm{O}$. The mixture was centrifuged and the precipitate dried. $\mathbf{A r g}_{3} \mathrm{Hyd}$ was freeze-dried and obtained as a white solid (48.8 mg, 46\%). ${ }^{1} \mathrm{H}$ NMR $\left(\mathrm{D}_{2} \mathrm{O} ; 400 \mathrm{MHz}\right) \delta 4.43-$ $4.37\left(\mathrm{~m}, 2 \mathrm{H}, 2 \mathrm{CH}-\mathrm{CH}_{2}\right), 4.12\left(\mathrm{t}, 3 \mathrm{~J}=6.4,1 \mathrm{H}, \mathrm{CH}-\mathrm{CH}_{2}\right), 3.26-3.23$ $\left(\mathrm{m}, 6 \mathrm{H}, 3 \mathrm{CH}_{2}-\mathrm{NH}\right), 1.99-1.80\left(\mathrm{~m}, 6 \mathrm{H}, 3 \mathrm{CHCH}_{2}\right), 1.76-1.61(\mathrm{~m}$, $\left.6 \mathrm{H}, 3 \mathrm{CHCH}_{2} \mathrm{CH}_{2}\right) ;{ }^{13} \mathrm{C}$ NMR $\left(\mathrm{D}_{2} \mathrm{O} ; 100 \mathrm{MHz}\right) \delta 173.6,171.6$, 169.7, 156.9, 53.7, 52.6, 52.0, 40.6, 40.4, 28.1, 28.0, 27.9, 24.4, 23.5; $[\alpha]_{D}^{20}:-5.6 \quad\left(\mathrm{H}_{2} \mathrm{O}, \quad \mathrm{c}=1.0\right)$; HR-ESI-MS: calcd for $\left[\mathrm{C}_{18} \mathrm{H}_{40} \mathrm{~N}_{14} \mathrm{O}_{3}+\mathrm{H}\right]^{+}$501.3486, found 501.3482.

General procedure for clusters synthesis through acylhydrazone ligation. 8 equivalents of hydrazide per scaffold were added from a $200 \mathrm{mM}$ stock solution in water into a 1 $\mathrm{mM}$ solution of scaffold $\mathbf{A}$ in aqueous buffer (100 mM AcONa, $\mathrm{pH}$ 5.0) and the mixture was stirred overnight at room temperature. The resulting cluster was analyzed by HPLC and MALDI-ToF or HR-ESI mass spectrometry. Clusters A8.Ac and A8.L-Arg were prepared as previously described. ${ }^{18}$

A8.Gly MALDI-ToF (HCCA): calcd for $\left[\mathrm{C}_{60} \mathrm{H}_{98} \mathrm{~N}_{26} \mathrm{O}_{18}+\mathrm{Na}\right]^{+}$ 1493.76, found 1493.72. A8.Gir HPLC: $t_{R} 6.83 \mathrm{~min}$; MALDI-ToF (HCCA): calcd for $\left[\mathrm{C}_{72} \mathrm{H}_{127} \mathrm{~N}_{26} \mathrm{O}_{18}+4 \mathrm{Cl}+\mathrm{Na}\right]^{+}$1805.98, found 1805.86. A8.Ala MALDI-ToF (HCCA): calcd for 
$\left[\mathrm{C}_{64} \mathrm{H}_{106} \mathrm{~N}_{26} \mathrm{O}_{18}+\mathrm{Na}\right]^{+}$1549.82, found 1549.81. A8.Asp MALDIToF (HCCA): calcd for $\left[\mathrm{C}_{68} \mathrm{H}_{107} \mathrm{~N}_{26} \mathrm{O}_{26}+\mathrm{Na}\right]^{+} 1726.78$, found 1725.76. A8.His MALDI-ToF (HCCA): calcd for $\left[\mathrm{C}_{76} \mathrm{H}_{115} \mathrm{~N}_{34} \mathrm{O}_{18}+\mathrm{Na}\right]^{+}$1814.91, found 1813.92. A8.Lys MALDIToF (HCCA): calcd for $\left[\mathrm{C}_{76} \mathrm{H}_{134} \mathrm{~N}_{30} \mathrm{O}_{18}+\mathrm{Na}\right]^{+}$1778.05, found 1777.99. A8.D-Arg MALDI-ToF (HCCA): calcd for $\left[\mathrm{C}_{76} \mathrm{H}_{134} \mathrm{~N}_{38} \mathrm{O}_{18}+\mathrm{H}\right]^{+}$1868.07, found 1868.05. A8.Lys 3 HPLC: $t_{R}$ $2.94 \mathrm{~min}$; MALDI-ToF (HCCA): calcd for $\left[\mathrm{C}_{124} \mathrm{H}_{231} \mathrm{~N}_{46} \mathrm{O}_{26}+\mathrm{Na}\right]^{+}$ 2803.82, found 2802.76. A8. $\mathbf{G}_{1}$-Lys HPLC: $t_{R} 4.66 \mathrm{~min}$; MALDIToF (HCCA): calcd for $\left[\mathrm{C}_{124} \mathrm{H}_{231} \mathrm{~N}_{46} \mathrm{O}_{26}+\mathrm{Na}\right]^{+}$2803.82, found 2802.79. A8. Arg $_{3}$ HPLC: $t_{R} 5.79$ min; MALDI-ToF (HCCA): calcd for $\left.\left[\mathrm{C}_{124} \mathrm{H}_{231} \mathrm{~N}_{70} \mathrm{O}_{26}+\mathrm{H}\right]\right]^{+} 3116.82$, found 3116.86. A1.Ac HPLC: $t_{R}$ $6.26 \mathrm{~min}$; HR-ESI-MS: calcd for $\left[\mathrm{C}_{9} \mathrm{H}_{10} \mathrm{~N}_{2} \mathrm{O}+\mathrm{Na}\right]^{+} 185.0871$, found 185.0870. A2.Ac HPLC: $t_{R} 7.40 \mathrm{~min}$; HR-ESI-MS: calcd for $\left[\mathrm{C}_{10} \mathrm{H}_{10} \mathrm{~N}_{2} \mathrm{O}_{2}+\mathrm{Na}\right]^{+}$213.0821, found 213.0819. A3.Ac HPLC: $t_{R}$ $6.78 \mathrm{~min}$; HR-ESI-MS: calcd for $\left[\mathrm{C}_{12} \mathrm{H}_{14} \mathrm{~N}_{4} \mathrm{O}_{2}+\mathrm{Na}\right]^{+}$269.1195, found 269.1197. A4.Ac HPLC: $t_{R} 6.92 \mathrm{~min}$; HR-ESI-MS: calcd for $\left[\mathrm{C}_{12} \mathrm{H}_{14} \mathrm{~N}_{4} \mathrm{O}_{2}+\mathrm{Na}\right]^{+}$269.1195, found 269.1197. A5.Ac HR-ESI-MS: calcd for $\left[\mathrm{C}_{9} \mathrm{H}_{16} \mathrm{~N}_{4} \mathrm{O}_{2}+\mathrm{Na}\right]^{+}$235.1171, found 235.1169. A6.Ac HPLC: $t_{R} 7.92$ min; HR-ESI-MS: calcd for $\left[\mathrm{C}_{15} \mathrm{H}_{18} \mathrm{~N}_{6} \mathrm{O}_{3}+\mathrm{Na}\right]^{+}$ 353.1519, found 353.1516. A7.Ac HPLC: $t_{R} 7.99 \mathrm{~min}$; MALDIToF (HCCA): calcd for $\left[\mathrm{C}_{62} \mathrm{H}_{98} \mathrm{~N}_{22} \mathrm{O}_{20}+\mathrm{Na}\right]^{+}$1493.73, found 1493.70.

\section{Acknowledgements}

We thank the CNRS, the LabEx CheMISyst (ANR-10-LABX-0501) and the ANR (ANR-11-PDOC-002-02) for funding. Automated peptide synthesis was carried out at the SynBio 3 platform - IBMM, Montpellier. We thank the ENSCM for the access to the fluorescence microplate reader. We thank Sarah Michel for her contribution to the peptide synthesis.

\section{References}

1 S. T. Crooke, Annu. Rev. Med., 2004, 55, 61-95;A.

Demesmaeker, R. Haner, P. Martin and H. E. Moser, Acc. Chem. Res., 1995, 28, 366-374;E. Uhlmann and A. Peyman, Chem. Rev., 1990, 90, 543-584.

2 J. C. Burnett, J. J. Rossi and K. Tiemann, Biotechnol. J., 2011, 6, 1130-1146;J. W. Gaynor, B. J. Campbell and R. Cosstick, Chem. Soc. Rev., 2010, 39, 4169-4184;D. Castanotto and J. J. Rossi, Nature, 2009, 457, 426-433.

3 M. A. Mintzer and E. E. Simanek, Chem. Rev., 2009, 109, 259302; S. Lehrman, Nature, 1999, 401, 517-518.

4 U. Lächelt and E. Wagner, Chem. Rev., 2015, DOI: 10.1021/cr5006793.

5 S. K. Samal, M. Dash, S. V. Vlierberghe, D. L. Kaplan, E. Chiellini, C. v. Blitterswijk, L. Moroni and P. Dubruel, Chem. Soc. Rev., 2012, 41, 7147-7194;D. N. Nguyen, J. J. Green, J. M. Chan, R. Longer and D. G. Anderson, Adv. Mater., 2009, 21, 847-867;S. Y. Wong, J. M. Pelet and D. Putnam, Prog. Polym. Sci., 2007, 32, 799-837;T. Merdan, J. Kopecek and T. Kissel, Adv. Drug Deliv. Rev., 2002, 54, 715-758.

6 X. X. Liu, P. Rocchi and L. Peng, New J. Chem., 2012, 36, 256263.
7 C. Fasting, C. A. Schalley, M. Weber, O. Seitz, S. Hecht, B. Koksch, J. Dernedde, C. Graf, E. W. Knapp and R. Haag, Angew. Chem. Int. Ed., 2012, 51, 10472-10498;G. V. Oshovsky, D. N. Reinhoudt and W. Verboom, Angew. Chem. Int. Ed., 2007, 46, 2366-2393;L. L. Kiessling, J. E. Gestwicki and L. E. Strong, Angew. Chem. Int. Ed., 2006, 45, 2348-2368; J. D. Badjic, A. Nelson, S. J. Cantrill, W. B. Turnbull and J. F. Stoddart, Acc. Chem. Res., 2005, 38, 723-732;A. Mulder, J. Huskens and D. N. Reinhoudt, Org. Biomol. Chem., 2004, 2, 3409-3424;M. Mammen, S. K. Choi and G. M. Whitesides, Angew. Chem. Int. Ed., 1998, 37, 2755-2794.

8 S. M. Moghimi, P. Symonds, J. C. Murray, A. C. Hunter, G. Debska and A. Szewczyk, Mol. Ther., 2005, 11, 990-995.

9 For examples of disulfide-based bioreducible polymers and dendrimers, see for instance: A. Barnard, P. Posocco, M. Fermeglia, A. Tschiche, M. Calderon, S. Pricl and D. K. Smith, Org. Biomol. Chem., 2014, 12, 446-455; L. D. Feng, A. Xie, X. Y. Hu, Y. Y. Liu, J. F. Zhang, S. F. Li and W. Dong, New J. Chem., 2014, 38, 5207-5214; K. L. Kozielski, S. Y. Tzeng and J. J. Green, Chem. Commun., 2013, 49, 5319-5321;H. M. Liu, H. Wang, W. J. Yang and Y. Y. Cheng, J. Am. Chem. Soc., 2012, 134, 17680-17687;S. Son, R. Namgung, J. Kim, K. Singha and W. J. Kim, Acc. Chem. Res., 2012, 45, 1100-1112;Y. Wang, R. Zhang, N. Xu, F. S. Du, Y. L. Wang, Y. X. Tan, S. P. Ji, D. H. Liang and Z. C. Li, Biomacromolecules, 2011, 12, 66-74;T. I. Kim, M. Lee and S. W. Kim, Biomaterials, 2010, 31, 17981804;J. G. Hardy, C. S. Love, N. P. Gabrielson, D. W. Pack and D. K. Smith, Org. Biomol. Chem., 2009, 7, 789-793;S.

Bauhuber, C. Hozsa, M. Breunig and A. Gopferich, Adv. Mater., 2009, 21, 3286-3306.

10 For examples of acid-sensitive materials, see for instance: C. Bouillon, D. Paolantoni, J. C. Rote, Y. Bessin, L. W. Peterson, P. Dumy and S. Ulrich, Chem. Eur. J., 2014, 20, 14705-14714; H. L. Cao, Y. X. Dong, A. Aied, T. Y. Zhao, X. Chen, W. X. Wang and A. Pandit, Chem. Commun., 2014, 50, 15565-15568;S.

Binauld and M. H. Stenzel, Chem. Commun., 2013, 49, 20822102;B. J. Hong, A. J. Chipre and S. T. Nguyen, J. Am. Chem. Soc., 2013, 135, 17655-17658;S. Duan, W. Yuan, F. Wu and T. Jin, Angew. Chem. Int. Ed., 2012, 51, 7938-7941;L. N. Cui, J. L. Cohen, C. K. Chu, P. R. Wich, P. H. Kierstead and J. M. J. Frechet, J. Am. Chem. Soc., 2012, 134, 15840-15848;A. Barnard, P. Posocco, S. Pricl, M. Calderon, R. Haag, M. E. Hwang, V. W. T. Shum, D. W. Pack and D. K. Smith, J. Am. Chem. Soc., 2011, 133, 20288-20300;J. A. Wolff and D. B. Rozema, Mol Ther, 2008, 16, 8-15;D. B. Rozema, D. L. Lewis, D. H. Wakefield, S. C. Wong, J. J. Klein, P. L. Roesch, S. L. Bertin, T. W. Reppen, Q. Chu, A. V. Blokhin, J. E. Hagstrom and J. A. Wolff, Proc. Natl. Acad. Sci. USA, 2007, 104, 1298212987;A. Aissaoui, B. Martin, E. Kan, N. Oudrhiri, M. Hauchecorne, J. P. Vigneron, J.-M. Lehn and P. Lehn, J. Med. Chem., 2004, 47, 5210-5223.

11 P. L. Padnya, E. A. Andreyko, O. A. Mostovaya, I. K. Rizvanov and I. I. Stoikov, Org. Biomol. Chem., 2015, 13, 5894-5904;V. Bagnacani, V. Franceschi, L. Fantuzzi, A. Casnati, G. Donofrio, F. Sansone and R. Ungaro, Bioconjugate Chem., 2012, 23, 993-1002;F. Sansone, L. Baldini, A. Casnati and R. Ungaro, New J. Chem., 2010, 34, 2715-2728;V. Bagnacani, F. Sansone, 
G. Donofrio, L. Baldini, A. Casnati and R. Ungaro, Org. Lett., 2008, 10, 3953-3956;F. Sansone, M. Dudic, G. Donofrio, C. Rivetti, L. Baldini, A. Casnati, S. Cellai and R. Ungaro, J. Am. Chem. Soc., 2006, 128, 14528-14536.

12 V. Bagnacani, V. Franceschi, M. Bassi, M. Lomazzi, G. Donofrio, F. Sansone, A. Casnati and R. Ungaro, Nat. Commun., 2013, 4, 1721

13 D. Sigwalt, M. Holler, J. lehl, J. F. Nierengarten, M. Nothisen, E. Morin and J. S. Remy, Chem. Commun., 2011, 47, 46404642.

14 Y. C. Chang, K. Yang, P. Wei, S. S. Huang, Y. X. Pei, W. Zhao and Z. C. Pei, Angew. Chem. Int. Ed., 2014, 53, 13126-13130; I. Nierengarten, M. Nothisen, D. Sigwalt, T. Biellmann, M. Holler, J. S. Remy and J. F. Nierengarten, Chem. Eur. J., 2013, 19, 17552-17558.

15 V. Villari, A. Mazzaglia, R. Darcy, C. M. O'Driscoll and N. Micali, Biomacromolecules, 2013, 14, 811-817;A. Martinez, C. Bienvenu, J. L. J. Blanco, P. Vierling, C. O. Mellett, J. M. G. Fernandez and C. Di Giorgio, J. Org. Chem., 2013, 78, 81438148;C. Bienvenu, A. Martinez, J. L. J. Blanco, C. Di Giorgio, P. Vierling, C. O. Mellet, J. Defaye and J. M. G. Fernandez, Org. Biomol. Chem., 2012, 10, 5570-5581;A. Mendez-Ardoy, N. Guilloteau, C. Di Giorgio, P. Vierling, F. Santoyo-Gonzalez, C. O. Mellet and J. M. G. Fernandez, J. Org. Chem., 2011, 76, 5882-5894;A. Diaz-Moscoso, L. Le Gourrierec, M. GomezGarcia, J. M. Benito, P. Balbuena, F. Ortega-Caballero, N. Guilloteau, C. Di Giorgio, P. Vierling, J. Defaye, C. O. Mellet and J. M. G. Fernandez, Chem. Eur. J., 2009, 15, 12871 12888;A. Diaz-Moscoso, P. Balbuena, M. Gomez-Garcia, C. O. Mellet, J. M. Benito, L. Le Gourrierec, C. Di Giorgio, P. Vierling, A. Mazzaglia, N. Micali, J. Defaye and J. M. G. Fernandez, Chem. Commun., 2008, 2001-2003;F. OrtegaCaballero, C. O. Mellet, L. Le Gourrierec, N. Guilloteau, C. Di Giorgio, P. Vierling, J. Defaye and J. M. G. Fernandez, Org. Lett., 2008, 10, 5143-5146.

16 X. Zhang, Z. Zhang, X. Xu, Y. Li, Y. Li, Y. Jian and Z. Gu, Angew. Chem. Int. Ed., 2015, 54, 4289-4294;X. X. Liu, J. H. Zhou, T. Z. Yu, C. Chen, Q. Cheng, K. Sengupta, Y. Y. Huang, H. T. Li, C. Liu, Y. Wang, P. Posocco, M. H. Wang, Q. Cui, S. Giorgio, M. Fermeglia, F. Q. Qu, S. Pricl, Y. H. Shi, Z. C. Liang, P. Rocchi, J. J. Rossi and L. Peng, Angew. Chem. Int. Ed., 2014, 53, 1182211827;S. P. Jones, N. P. Gabrielson, C. H. Wong, H. F. Chow, D. W. Pack, P. Posocco, M. Fermeglia, S. Pricl and D. K. Smith, Molecular Pharmaceutics, 2011, 8, 416-429;D. J. Welsh, S. P. Jones and D. K. Smith, Angew. Chem. Int. Ed., 2009, 48, 40474051;S. P. Jones, N. P. Gabrielson, D. W. Pack and D. K. Smith, Chem. Commun., 2008, 4700-4702;M. A. Kostiainen, J. G. Hardy and D. K. Smith, Angew. Chem. Int. Ed., 2005, 44, 2556-2559.

17 G. M. Pavan, M. A. Kostiainen and A. Danani, Rsc Adv, 2011, 1, 1677-1681;P. Posocco, S. Pricl, S. Jones, A. Barnard and D. K. Smith, Chem Sci, 2010, 1, 393-404;G. M. Pavan, A. Danani, S. Pricl and D. K. Smith, J. Am. Chem. Soc., 2009, 131, 96869694.

18 E. Bartolami, Y. Bessin, V. Gervais, P. Dumy and S. Ulrich, Angew. Chem. Int. Ed., 2015, DOI: 10.1002/anie.201504047.
19 C. Gehin, J. Montenegro, E.-K. Bang, A. Cajaraville, S. Takayama, H. Hirose, S. Futaki, S. Matile and H. Riezman, J. Am. Chem. Soc., 2013, 135, 9295-9298;J. Montenegro, E. K. Bang, N. Sakai and S. Matile, Chem. Eur. J., 2012, 18, 1043610443;J. Montenegro, A. Fin and S. Matile, Org. Biomol. Chem., 2011, 9, 2641-2647;J. Montenegro, P. Bonvin, T. Takeuchi and S. Matile, Chem. Eur. J., 2010, 16, 1415914166.

20 Y. C. Huang, C. C. Chen, S. J. Li, S. Gao, J. Shi and Y. M. Li, Tetrahedron, 2014, 70, 2951-2955.

21 D. L. Boger, B. E. Fink, S. R. Brunette, W. C. Tse and M. P. Hedrick, J. Am. Chem. Soc., 2001, 123, 5878-5891.

22 K. E. Hauschild, J. S. Stover, D. L. Boger and A. Z. Ansari, Bioorg. Med. Chem. Lett., 2009, 19, 3779-3782.

23 C. D. Carlson, C. L. Warren, K. E. Hauschild, M. S. Ozers, N. Qadir, D. Bhimsaria, Y. Lee, F. Cerrina and A. Z. Ansari, Proc. Natl. Acad. Sci. USA, 2010, 107, 4544-4549;W. C. Tse and D. L. Boger, Acc. Chem. Res., 2004, 37, 61-69.

24 G. Gasparini, E.-K. Bang, J. Montenegro and S. Matile, Chem. Commun., 2015, 51, 10389-10402;A. Mann, G. Thakur, V. Shukla, A. K. Singh, R. Khanduri, R. Naik, Y. Jiang, N. Kalra, B. S. Dwarakanath, U. Langel and M. Ganguli, Mol. Pharmaceutics, 2011, 8, 1729-1741.

25 H. Y. Kuchelmeister, S. Karczewski, A. Gutschmidt, S. Knauer and C. Schmuck, Angew. Chem. Int. Ed., 2013, 52, 1401614020.

26 S. Foillard, M. O. Rasmussen, J. Razkin, D. Boturyn and P. Dumy, J. Org. Chem., 2008, 73, 983-991.

27 C. Kay, O. E. Lorthioir, N. J. Parr, M. Congreve, S. C. McKeown, J. J. Scicinski and S. V. Ley, Biotechnol Bioeng, 2000, 71, 110-118. 